Portland State University

PDXScholar

$11-9-1988$

\title{
A Comparative Study of Chinese EFL Reading Instruction and American ESL Reading Instruction
}

Changhua Wang

Portland State University

Follow this and additional works at: https://pdxscholar.library.pdx.edu/open_access_etds

Part of the Applied Linguistics Commons, and the Bilingual, Multilingual, and Multicultural Education Commons

Let us know how access to this document benefits you.

\section{Recommended Citation}

Wang, Changhua, "A Comparative Study of Chinese EFL Reading Instruction and American ESL Reading Instruction" (1988). Dissertations and Theses. Paper 3861.

https://doi.org/10.15760/etd. 5745

This Thesis is brought to you for free and open access. It has been accepted for inclusion in Dissertations and Theses by an authorized administrator of PDXScholar. Please contact us if we can make this document more accessible: pdxscholar@pdx.edu. 
AN ABSTRACT OF THE THESIS OF Changhua Wang for the Master of Arts in TESOL presented November 9, 1988.

Title: A Comparative Study of Chinese EFL Reading Instruction and American ESL Reading Instruction.

APPROVED BY MEMBERS OF THE THESIS COMMITTEE:
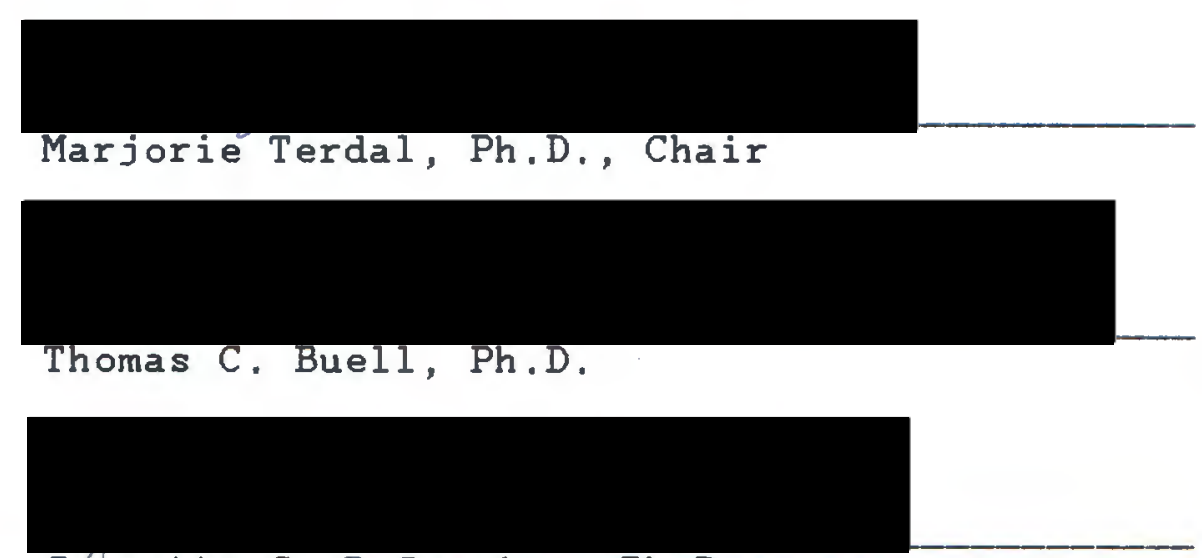

Jfanette S. DeCarrico, Ph.D.

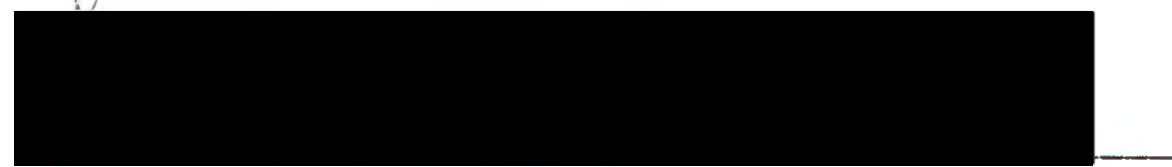

Jonathan O. Pease, Ph.D.

Reading instruction in China and that in the United States are so different that they are not compatible. In fact, they seem to go in opposite directions. This study examined some of the differences between Chinese EFL reading instruction and American ESL reading instruction through analyzing selected tape-recordings of reading classes from China and the United States, and comparing Chinese EFL reading textbooks with American ESL reading textbooks. 
This study was intended to answer the following questions.

1. Is a bottom-up method of reading really taught in China while a top-down method is taught in the United States?

2. Compared with the ESL reading textbooks used in the United States, do the Chinese EFL reading textbooks have a larger proportion of exercises dealing with vocabulary, grammar and pronunciation and fewer items in reading skills ?

3. Compared with the American ESL subjects, what are the strengths and weaknesses of the Chinese EFL subjects in reading comprehension in terms of recognizing main ideas, understanding direct statements and drawing inferences?

The results of the study suggest that a bottom-up way of reading is taught in China and a top-down way of reading is taught in the United States. The Chinese EFL reading classes had larger proportions of statements about vocabulary, grammar and pronunciation while the American ESL reading classes had larger proportions of statements about reading skills. It was also the case with the American ESL reading textbooks and the Chinese EFL reading textbooks. The rationale behind the reading textbooks is in comformity with what is practiced in the reading classes. Reading methods, however, are not necessarily correlated with students' performance in reading. 
A COMPARATIVE STUDY OF CHINESE EFL

READING INSTRUCTION AND AMERICAN ESL READING INSTRUCTION

by

CHANGHUA WANG

A thesis submitted in partial fulfillment of the requirements for the degree of

\section{MASTER OF ARTS}

in

TESOL

Portland State University

1988 
TO OFFICE OF GRADUATE STUDIES:

The members of the committee approve the thesis of Changhua Wang presented November 9, 1988.
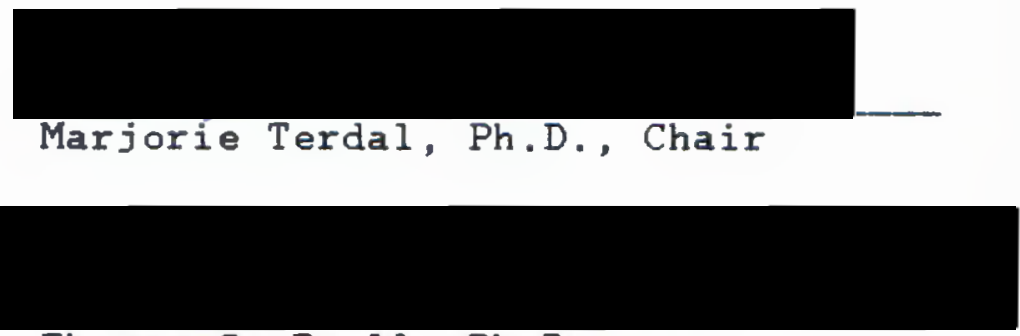

Thomas C. Buell, Ph.D.

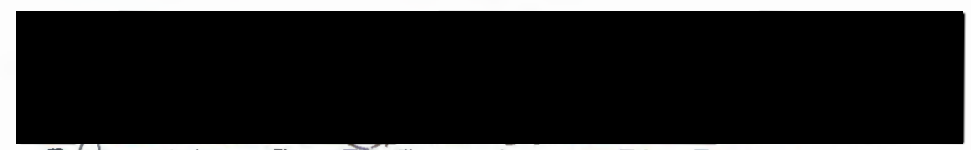

Jéanette S. DeCarrico, Ph.D.

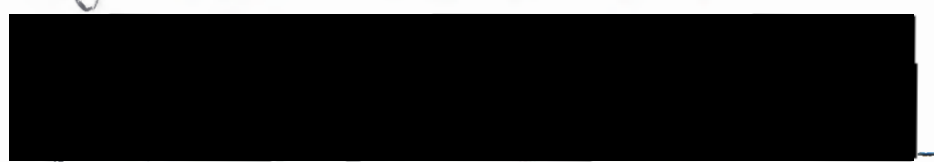

Jonathan O. Pease, Ph.D.

APPROVED:

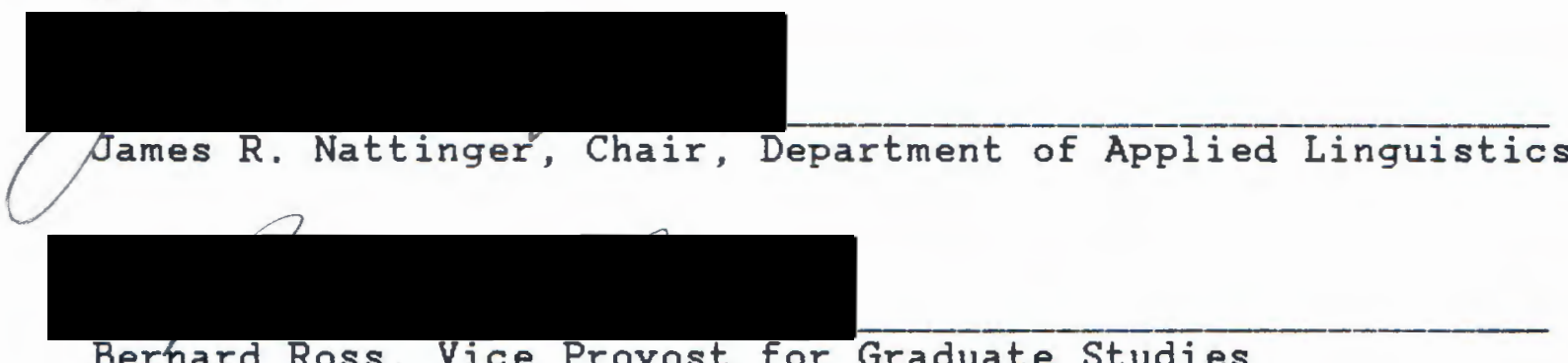

Berhard Ross, Vice Provost for Graduate Studies 


\section{ACKNOWLEDGEMENTS}

I am very grateful to Lynn and Chris Thompson, Michael and Norma Slover, Jack and Carole knight, stan and Valene McIntyre, Eva Hoenig, Henry Nass and my other American friends, who have made my graduate studies in the Unites states possible.

I am very grateful to my adviser, Dr. Marjorie Terdal, for her guidance and help at the every step of the design and the writing of the thesis. Without her sacrifice of many weekends to read the drafts of the thesis, the completion of it would have been more difficult.

I would also like to express my sincere thanks to other members of the thesis committee for their constructive comments and sugguestions, which make the thesis more readable.

Last, but not the least, my sincere thanks go to my wife, suping for her support and assistance in the whole study • 
TABLE OF CONTENTS

PAGE

ACKNOWLEDGEMENTS $\ldots \ldots \ldots \ldots \ldots \ldots \ldots \ldots \ldots \ldots \ldots$ ii

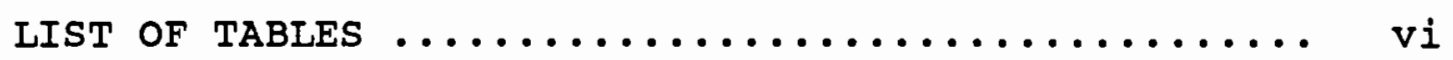

IIST OF FIGURES $\ldots \ldots \ldots \ldots \ldots \ldots \ldots \ldots \ldots \ldots \ldots \ldots \ldots \ldots \ldots$

\section{CHAPTER}

I INTRODUCTION $\ldots \ldots \ldots \ldots \ldots \ldots \ldots \ldots \ldots \ldots \ldots$ I

II REVIEW OF RELATED IITERATURE $\ldots \ldots \ldots \ldots \ldots \ldots$

Understanding the Nature of the Reading

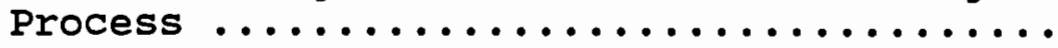

Some Definitions of Reading

Oral Reading vs. Silent Reading

Reading for Meaning

Teaching of English Reading in China ..... 22

Intensive Reading and Extensive Reading

Causes for Popularity of Intensive Reading

III METHOD $\ldots \ldots \ldots \ldots \ldots \ldots \ldots \ldots \ldots \ldots \ldots \ldots \ldots \ldots$

sujects $\ldots \ldots \ldots \ldots \ldots \ldots \ldots \ldots \ldots \ldots \ldots$

Procedures and Design ............. 34

IV RESULTS $\ldots \ldots \ldots \ldots \ldots \ldots \ldots \ldots \ldots \ldots \ldots \ldots . \ldots \ldots$

Chinese EFL Reading Instruction and American

ESL Reading Instruction ............ 40

Chinese EFL Reading Textbooks and American

ESL Reading Textbooks ..............

Reading Comprehension ............ 46

v SUMMARY AND DISCUSSION ............. 54 
Summary ...................... 54

Discussion ..................... 56

Interpretation of Results

Iimitation of the study

Implication and Conclusion $\ldots \ldots \ldots \ldots$

REFERENCE

A. Sample coding of Classroom Reading Instruction

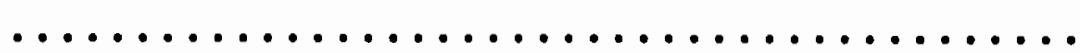

B. Sample Coding of Exercises in Reading

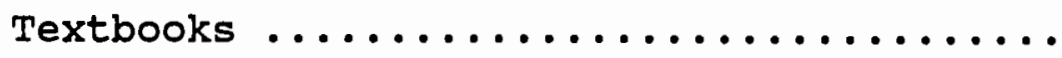

c. Sample Questions from Reading Comprehension

Test $\ldots \ldots \ldots \ldots \ldots \ldots \ldots \ldots \ldots \ldots . \ldots \ldots \ldots$

D. Reading Scores and Testing Time from NAI and 
LIST OF TABLES

TABLE

PAGE

I Frequency Counts of Focus in American ESL

Classes and Chinese EFI Reading Classes...... 41

II Logistic Regression Analysis for Reading Skills 41

III Logistic Regression Analysis for Vocabulary.... 42

IV Logistic Regression Analysis for Grammar...... 42

$V$ Logistic Regression Analysis for Pronunciation 43

VI Percentage of Exercises in Chinese EFI Reading Textbooks and American ESI Reading Textbooks... 44

VII Logistic Regression Analysis for Exercises

about Reading skills..................... 44

VIII Logistic Regression Analysis for Exercises

about vocabulary........................ 45

IX Logistic Regression Analysis for Exercises

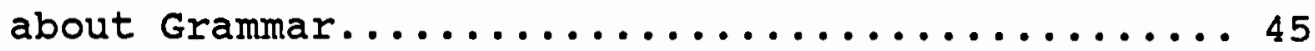

$\mathrm{x}$ Logistic Regression Analysis for Exercises

about Pronunciation...................... 46

XI Mean and Standard Deviation for scores on Item 146

XII one-way ANOVA for scores on Item $1 \ldots \ldots . \ldots . \ldots$

XIII Mean and Standard Deviation for Scores on Item 47

XIV One-way ANOVA for scores on Item 2...........48

XV Mean and standard Deviation for Scores on Item 348

XVI One-way ANOVA for scores on Item 3...........48 
XVII Mean and Standard Deviation for Total Scores of the Test...................... 49

XVIII one-way ANOVA for Total scores of the Test.... 49

XIV One-way ANOVA for Proportion of the Three Items in the Test.................... 50

$\mathrm{XX}$ One-way ANOVA for Means of the Test......... 50

XXI One-way ANOVA for the Testing Time and the Reading scores on Item $1 \ldots \ldots \ldots \ldots \ldots \ldots \ldots \ldots$

XXII One-way ANOVA for the Testing Time and the Reading scores on Item $2 \ldots \ldots \ldots \ldots \ldots \ldots \ldots \ldots \ldots$ XXIII One-way ANOVA for the Testing Time and the Reading scores on Item $3 \ldots \ldots \ldots \ldots \ldots \ldots \ldots$ XIV One-way ANOVA for the Testing Time and the Total score on the Three Items............ 53 


\section{LIST OF FIGURES}

FIGURE

PAGE

1. A Model of Oral Reading at Early Stage..... 12

2. A Model of Oral Reading at Proficient Level.. 12

3. Testing Time and Reading Scores from NAI.... 51

4. Testing Time and Reading Scores from PSU.... 52 


\section{CHAPTER I}

\section{INTRODUCTION}

Reading instruction in the People's Republic of China and that in the United States are so different, as some English as a Second Language(ESL) specialists have reported, that they are not compatible. In fact, they seem to go in opposite directions. The goal of this thesis is to examine some of the differences between Chinese EFL (English as a foreign language) reading instruction and American ESL reading instruction through analyzing selected taperecordings of reading classes from China and the U.S., comparing the reading scores of American ESL students with those of Chinese EFL students, and comparing Chinese EFL reading textbooks with American ESL reading textbooks.

It is hoped that the findings in this thesis will be mutually beneficial: on the one hand, American ESL teachers will be better prepared to teach English in China if they understand the differences and on the other hand, Chinese teachers may find it necessary to modify their curriculum or way of training if they want to prepare their students to study in the United States. 


\section{A BROAD VIEW OF TEACHING OF READING \\ IN CHINA AND THAT IN THE UNITED STATES}

In China, reading instruction is primarily conducted in classes of "intensive" reading or close-reading. The approach to language instruction always involves a detailed examination of short texts. Classroom procedures requiring students and teachers to concentrate their attention on the reading of individual words and phrases dominate the instruction. Both textbooks and teachers provide students with explanations for all potentially difficult items. During class the teacher explains word meanings and offers numerous analyses of grammatical structures.

In the United States, reading is now normally viewed as a silent process, the speed of which contributes to efficiency in comprehension. That is to say, the speed of reading is positively correlated with the comprehension of a text. The rationale for the current American psycholinguistic approach to reading is based on theoretical models and recent research. This rationale, which has been evolving for at least twenty years, is the product of Kenneth Goodman's "psycholinguistic guessing game" model (1967), Frank Smith's analysis of the reading process (1971), and the work of many other psycholinguists, cognitive psychologists and educators. Although American reading specialists are not in complete agreement about the 
nature of the reading process, most do agree that the rapid processing of a text contributes significantly to reading comprehension.

Fischer-Kohn(1986) summarizes the diferences between reading instruction in China and that in the United States. Most Chinese teachers encourage students, 1) to read slowly so as to understand each word as they go; 2) to reread difficult sentences until they are understood; 3) to vocalize the material, either aloud or silently; 4) to look up definitions for all unknown words in a dictionary; and 5) analyze complex grammatical structures carefully. In contrast, most American teachers suggest that students: 1) read rapidly; 2) take care to avoid vocalization or regression; 3) use prior background knowledge to predict what a reading may be about; 4) focus on the main ideas rather than treating every phrase as equally important; and 5) guess the meaning of words from the context whenever possible, avoiding frequent use of a dictionary.

This short list of differences in reading instruction fits respectively into a "bottom-up" way of reading and a "top-down" way of reading. "Bottom-up", means that the Chinese teachers put emphasis on lower-order cognitive processes such as the analysis of words and syntax. Chinese students are taught to read from the concrete to the abstract, from individual words to the whole idea of a text. The opposite approach is used with American students. 
American teachers employ a "top-down" way of reading by putting emphasis on higher-order cognitive processes such as the integration of ideas in a whole text. Words and syntax are often dealt with in context when they are liable to block the comprehension of a text if not explained.

\section{RESEARCH QUESTIONS AND HYPOTHESES}

In order to examine some of the differenega freanted by Fischer-Kohn, three research questions are raised in this thesis. Each of them leads to a hypothesis to be tested by analyses of classroom recordings, comprehension scores and reading textbooks.

1. Is a bottom-up method of reading really taught in China while a top-down method is taught in the United States ?

Hypothesis: Chinese teachers in EFL reading classes focus on vocabulary, grammar and pronunciation more often than American ESL teachers and less often on reading skills, such as summarizing main ideas, drawing inference of meanings and figuring out meaning of lexical items from the context.

2. Compared with ESL reading textbooks used in the United States, do EFL reading textbooks written by Chinese scholars have a larger proportion of exercises dealing with vocabulary, grammar and pronunciation, and fewer items in reading skills ? 
Hypothesis: Chinese EFL Reading textbooks will have larger a proportion of exercises dealing with vocabulary, grammar and pronunciation, and fewer items in reading skills.

3. Compared with American ESL students, what are the strengths and weaknesses of Chinese EFL students in reading comprehension in terms of recognizing main ideas, understanding direct statements and drawing inferences ? Hypotheses:

A. Chinese EFL students will score lower in all items than American ESL students.

B. Chinese EFL students will score lower in understanding main ideas and drawing inferences than in understanding direct statements .

C. The reading speed of Chinese EFL students is slower than that of American ESL students.

The variables in the hypothesis to the first research question will be measured by proportions of teachers' statements about reading skills, vocabulary, grammar and pronunciation in reading classrooms. The variables in the hypothesis to the second research question will be measured by proportions of exercises about reading skills, vocabulary, grammar and pronunciation in reading textbooks. The variables in the hypotheses to the third research questions will be measured by students' reading scores of a reading comprehension test and their testing time. The ways 
of measuring the above variables will be fully described in the methods chapter of the thesis. 


\section{REVIEW OF RELATED LITERATURE}

This chapter will be divided into two parts. The first part will review literature concerning rationale and research evidence which support the guidelines (listed in Chapter I) that most American teachers follow in teaching of reading. The second part will discuss teaching of English as a foreign language in China. The rationale behind the preference for intensive reading or close-reading will also be discussed in this part.

\section{UNDERSTANDING THE NATURE OF THE READING PROCESS}

Perhaps the most salient way of understanding American reading instruction is to see how the nature of the reading process is understood. Although the complexity of the reading process makes it difficult to describe and explain, the results of research in the reading process have already found their influence in reading classrooms.

\section{Some Definitions of Reading}

The definitions presented here are by no means inclusive, but they represent the major trend or shift in 
understanding the nature of the reading process in the United States. By looking at these definitions, we will be able to gain a general idea of directions in reading instruction from different points of view. The following definitions and characteristics of the reading process are arranged from superficial to sophisticated rather than chronologically. Since some of the definitions overlap with each other in real classroom teaching, there is probably no reading program which is confined to one of the defintions with total exclusion of others. But one definition tends to remain dominant throughout a reading program (Chall 1967, Smith 1965).

A. Reading means getting meaning from certain combinations of letters (Flesch 1955, P.10).

B. Reading is a precise process. It involves exact, detailed sequential perception and identification of letters, words, spelling patterns and larger language units (a view denounced in Goodman 1967 P.126).

$C$. The linguist conceives the reading act as that of turning the stimulus of the graphic shapes on the surface back into speech. The shapes represent speech, meaning is not found in marks but in speech which the marks represent (Strickland 1964, p.10).

D. Corresponding to the auditory anlysis of a sentence the skill of reading can be viewed as the ability to extract from a visual signal the underlying structure of sentences (Bever and Bower 1966, P.20).

E. Reading is the active process of reconstructing meaning from language represented by graphic symbols(letters), just as listening is the active process of reconstructing meaning from the sound symbols (phonemes) of oral language (Smith, Goodman, and Meredith 1970,p147). 
F. Reading is a psycholinguistic guessing game. It involves an interaction between thought and language. Efficient reading does not result from precise perception and identification of all elements, but from skill in selecting the fewest, most productive cues necessary to produce guesses which are right the first time (Goodman 1967, p. 127).

G. When the light rays from the printed page hit the retinal cells of the eyes, signals are sent along the optic nerve to the visual centers of the brain. This is not yet reading. The mind must function in the process, the signals must be interpreted and the reader must give significance to what he reads. He must bring meaning to the graphic symbols (Dechant 1965, p.12).

From Definition A to Defintion G, we can clearly see the shift from a superficial view of reading to a sophisticated psycholinguistic view of reading. The superficial view of reading is based on the following assumptions: 1) words are formed with letters; therefore identification of words depends on the identification of individual letters; 2) since a sentence consists of individual words, the combination of all these words will produce meaning automatically and 3) since written symbols are representation of speech, the meaning can only result from transforming the written word into speech; e.g., if one knows the sound he knows the meaning (Holmes 1971).

The psycholinguistic view of reading is different from the superficial view of reading in a sense that the study of reading is no longer confined to the area of linguistics and reading is no longer considered a passive process, but a receptive process, in which the reader plays an active 
role in bringing meaning to the reading. Psycholinguistics, as its name suggests, is a field of study that lies at the intersection of two broader disciplines, psychology and linguistics. The role of psycholinguistics in studying language learning is undoubtedly more powerful than that of either linguistics or psychology considered separately. How psycholinguistics can be related to reading instruction can be explained by the fact that linguistics has developed an understanding and an explanation of language processing while psychology focuses on the enhancement of the ability to decode and comprehend language (Ruddell 1972).

Psycholinguistics has broadened the area of research in reading. It is unusual to find a psycholinguistic paper about reading that deals with just a self-contained topic. The psycholinguistic view of reading makes it possible for us to think that there are many factors which determine the success or failure of reading. These factors are not necessarily restricted to the area of language. Despite the strength of psycholinguistics, there is no "psycholinguistic method" for the teaching of reading. The value of psycholinguistics lies in the insights it provides into the process of reading (Smith and Goodman 1971). Its value lies in the new understanding it can give researchers and practitioners about the reading process and learning to read. Frank Smith (1973) lists the following insights that psycholinguistics provides into the process of reading. 
1. Only a small part of the information necessary for reading comprehension comes from the printed page.

2. Comprehension must precede the identification of words.

3. Reading is not decoding to spoken language (P.8).

These insights have certainly generated many topics in the study of reading, such as selective information processing in reading, the role of word identification, and the relation between written language and spoken language. The following sections of this literature review discuss relevant issues of the reading process central to the topic of the thesis.

\section{Oral I Reading vs. Sillent Reading}

Despite the fact that reading in actual life is to be mainly silent reading, reading as a school exercise has often been thought of as reading aloud. This section will discuss the differences between oral reading and silent reading and why silent reading is in many respects superior to oral reading.

An examination of the literature suggests that there are two major emphases in the teaching of reading. One is an emphasis on reading as the decoding of written symbols, that is, a concern with orthography. The other is an emphasis on reading for meaning, that is, a concern with mental processes of a fairly high order. When the emphasis is on code, there is likely to be a concentration on 
phonics, on phoneme-grapheme correspondences, and on using oral reading as part of the teaching process. An emphasis on the message will lead to a concentration on the meaningful context, and on the avoidance of oral reading in favor of silent reading (Wardhaugh 1972). Obviously oral reading is taught to help decode written symbols. Oral reading at an early stage can be described by the following simplified model.

Graphic Recodes $\left[\begin{array}{lll|l|} & \text { Oral } & < & \text { Auray } \\ \text { Output< } & \text { Input } & \text { Decodes } & \text { Meaning }\end{array}\right.$

Figure 1. A model of oral reading at early stage (Goodman 1968)

It is not unusual to find readers who can pronounce words correctly without understanding their meanings. This is described as word-calling or recoding which by itself is not reading at all. Oral reading which is fluent and accurate may involve simultaneous recoding and decoding. But for most proficient silent readers, who do not have much occasion for oral reading, oral reading apparently follow the model:

Figure 2. A model of oral reading at proficient level (Goodman and Niles in Gollasch ed. 1982) 
The reading model in Figure 1 is different from the model in Figure 2, though both are descriptions of oral reading. In Figure 2 , oral output is produced after meaning has been decoded while in Figure 1 , meaning comes after the oral output. Oral reading in Figure 2 is workable, though it is slow. However, oral reading in Figure 1 does not always work due to the fact that accurate output often depends on meaning.

Individual written words do not carry any information about how they should be articulated. A list of words such as "minute on permit print read should the the we" can not be read with anything but what is called "list intonation", which is quite different from the intonation the same words get when put together in the sequence, "we should read the minute print on the permit." Before we comprehend the sentence, we may utter this sentence in different ways. The decision to pronounce permit as a noun /'po:mit/ instead of a verb/pa:'mit/, read as /ri:d/ instead of /red/, /main'ju:t/ instead of /'minit/ is determined by the meaning of the sentence as whole (Smith 1973). Therefore we can not produce the accurate oral output before decoding the meaning.

Silent reading is, however, never burdened by oral output. The whole process of silent reading is meaningcentered as Goodman has stated,

When silent reading becomes proficient, it becomes a different process from oral reading. It is much more 
rapid and not tied to encoding what is being read as speech. In silent reading, the reader sweeps ahead sampling from the graphic input, predicting structures, leaping to quick conclusions about the meaning and slowing down or regressing when subsequent sampling fails to confirm what he expects to find (in Gollasch ed. Vol 2,1982, P.110).

The difference between reading aloud and reading silently can also be easily demonstrated: almost no one can read aloud intelligibly at the rate of 300 words per minute. The silent rate can be much higher. Oral reading is involved with word-by-word identification in order to produce the sound of each word. The limit of oral reading makes speed reading impossible, which is crucial in comprehension. Unlike oral reading, the speed reader reads by utilizing just part of the information available from every word, diluting a minimum of visual information with a maximum of uncertainty-reducing redundancy (Smith 1973). The reason that reading has to be silent and fast is that the processing of visual information is not instantaneous but takes a significant amount of time, during which losses in comprehension often occur. Speed reading helps us to "chunk" the information while slow reading, such as oral reading, makes storage of information in short term memory very difficult. The faster we read, the easier we will remember; the slower we read, the faster we will forget. It has been generally accepted that there is a limit to the amount of information that we are able to receive, process and remember (Miller 1967). The reader, therefore, 
does not use all the information on the page, but rather, must select the most productive language cues in determining the message of the writer. From this it follows that reading is necessarily a rapid process which could not proceed word by word. Miller (1967) has found that unrelated words can not be read at the same rate as meaningful text, and it is very difficult indeed to extract meaning from words that are read slowly.

The fact that some readers tend to read aloud or subvocalize when they come across difficult words or phrases is often used as an argument for reading aloud or subvocalization. But there is no clear evidence that reading aloud or subvocalization helps us understand better. Goodman (1968) points out that we tend to subvocalize only when our reading slows down instead of slowing down our reading to subvocalize. Subvocalization or reading aloud can not make a difficult passage easy because even if every word is articulated, there is still the problem of working out what it means. The meaning of language is no more given directly in its sound than it is available in the surface structure of writing.

From the preceding discussion we may conclude that silent reading and oral reading are different in terms of process and function. Silent reading is a prerequisite for speed reading, which enhances comprehension, while oral reading can only result in slow reading, which inhibits 
comprehension to a great extent. Efficient reading requires the reader to read silently and quickly at the same time.

\section{Reading for Meaning}

According to Goodman (1968), to get meaning from a text is the ultimate goal of reading. Reading can never be complete unless the reader brings meaning to what he is reading.

The diversity of reading instruction or reading methods can be summarized as an answer to the following question: does the fluent reader identify individual words to obtain the meaning of a passage or does s/he obtain the meaning of a passage to identify individual words (Smith 1978)? As discussed above, skilled readers read too fast to identify every word, but to say word identification is non-existent in reading is not truthful. The question to be answered here is: which comes first, meaning or word identification ? There is considerable evidence that reader reads for meaning rather than for word identification. Goodman (1965) and Weber (1968) found that many of the errors that skilled and beginning readers make are visual rather than semantic. For example, the word "said" is more likely to be misread in context as "told" ( a visual but not semantic error) than as its shapemate "sand" ( visually relatively accurate but semantically anomalous). The psycholinguistic evidence indicates that we remember sentences for their meaning 
rather than for their specific words (Mehler 1963), and the classic study of Bartlett (1932) shows that meanings rather than words are retained in long-term memory. Slobin (1965) demonstrated that children's repetitions of spoken sentences reproduce meaning rather than the precise words or sentence structure. Kolers(1968) reports that bilinguals who read texts which switch every few words between one language and another frequently make transposition errors in which they read the right word in the wrong language. American subjects sometimes pronounced "moats" as the French word "mots" and "warden" as "vahrdhan". Native speakers of French, on the other hand, pronounced "murs" as English "moor".

"A good reader is a good cheater." This aphorism reflects the common observation that readers, at least, those beyond the initial mastery of the skill, do not attend equally to every element of the text. The eye-movement of speed readers can serve as an example for this. In order to get meaning from a passage the reader's eye movement does not necessarily follow what is often thought as a regular pattern; from right to left, from top to bottom. Instead the eye movements of skilled readers are irregular. Taylor (1957) found that no systematic pattern characterizes the eye movements of speed readers. The same people were variable from page to page, and different people scanned the same page in different ways. The significance of this 
finding indicates that reading is not word-by-word identification in a linear order.

The theory of the transformational linguists (Chomsky 1957, Chomsky 1965, Jacobs and Rosenbaum 1968, and Akmajion and Heny 1975) also supports the view that the fluent reader has to read directly for meaning, because words represent only the surface structure of langauge. A compeling illustration of the manner in which we read for meaning instead of surface level of language can be found in the way sentences are remembered. It is, of course, very rare that sentences of seven or eight words or more, or sentences heard more than a few minutes previously, can be repeated word for word correctly. But the errors of recall that are made are usually related to a specific word, or to the syntactic structure of the sentence, rather than to the meaning of the sentence as a whole (Mehler and Miller 1964).

Schema theory can also be used to explain the fact we read for meaning. The essense of schema theory is that concepts can have meaning when they are related to something the individual already knows. Reading for meaning or the process of interpretation, according to schema theory, is guided by the principle that every input is mapped against some existing schema and that all aspects of that schema must be compatible with input information.

This principle results in two basic modes of information processing, bottom-up process and top-down 
process. Bottom-up processing is evoked by the incoming data; the features of data enter the system through best fitting, bottom level schema. As these schemata converge into higher level schemata, these two are activated. Bottom -up processing is, therefore, called data driven. Top-down processing occurs as the system searches the input for information to fit into partially satisfied, higher order schemata. Top-down processing is, therefore, called conceptually-driven (Carrell 1983A). Bottom-up processing ensures that the listeners/readers will be sensitive to information that is novel or that does not fit their ongoing hypotheses about the content or structure of the text; top-down processing helps the listeners/readers to resolve ambiguities or to select between alternative possible interpretations of the incoming data (Carrell and Eisterhold, 1983).

In the process of reading, readers when using bottomup processing will go from smaller units of analysis in text to larger ones. Roughly, features of letters are detected, letters are recognized, strings of letters are identified as words, concatenated words are analyzed to determine sentence meaning, and finally, sets of sentences are considered together to produce the meaning of a connected discourse. When top-down processing is used, readers will pay much more attention to factors outside of the text and employ preexisting knowledge of the topics dealt with in the 
text and knowledge-based determination of the relative importance of information in the text (cf.Anderson and Pichert 1978, Bransford and McCarrel 1975, Spiro 1977). The understanding of a text is actively constructed much like a building, from "blueprints" based in part on text information and from input on contextual factors.

Background knowledge plays an important role in helping us read for meaning. To understand what is background knowledge, it is often useful to draw a distinction between formal schemata and content schemata. Carrell (1983B) explains the distinction: formal schemata refers to background knowledge of the formal, rhetorical organizational structures of different type of texts. Content schemata refers to background knowledge of the content area of a text (Carrell 1983B). Carrell's research has shown that both formal schemata and content schemata have a strong impact on reading comprehension when the other form of schemata remains constant.

An experiment by Anderson, Reynold, Schaller, and Goetz (1976) has shown different comprehension results from differences in schemata (background knowledge). They presented a passage to two groups of college students of different majors. These two groups had totally different interpretations of the same passage. Each group of students interpreted the passage within their familar schemata. Several recent studies have shown the effects of 
formal, rhetorical schemata in ESL/EFL. In a study by Carrell(1981), two groups of university-bound, intermediate-level ESL subjects were asked to read stories written differently. One group read stories well structured according to a simple story schemata structure and the other group read stories which were purposely poorly structured so as to violate the story schemata structure. Results showed that when stories violating the story schemata were processed by second language learners, both the quality of recall and the temporal sequence of recall were affected. Reading for meaning can be summarized by Goodman's model of the psycholinguistic guessing game (1967), in which he stated that the reading process is not a precise process, but a selective process. How much information will be used in reading depends on the reader's expectation. In processing this partial information, the reader makes a tentative decision to confirm or reject his/her predictions. Similar to the model of reading as a psycholinguistic guessing game, Hidrith (1958) defines reading as follows.

Reading requires inference, weighing the relative importance of ideas and meanings and seeing the relationship among them; it is a process of forming tentative judgements, then verifying and checking guesses. To solve the problems in a passage the reader must be continuously in an alert, anticipating frame of mind, suspending judgements, correcting and confirming his guesses as he goes al ong ( $\mathrm{p} .72)$. 


\section{TEACHING OF ENGLISH READING IN CHINA}

Compared with other language skills, reading skills in China are considered the most important skills in English learning. This is certainly a reflection of the wide belief that other language skills such as speaking and writing result from the ability to read. The following review will briefly describe how English reading is taught in China and why intensive reading or close-reading is preferred there.

\section{Intens $\underline{i v e}$ eㅡeading_and__Extensive Reading}

In China, English reading is taught in two ways: one is Intensive Reading and the other Extengive Reading. These two approaches were originally intended to be complementary with each other. In Intensive Reading, a thorough understanding of linguistic items is absolutely required. Usually six to eight hours (that is, one to two weeks) is spent on a lesson of three to eight pages. Language points -- phonological, grammatical, and lexical-- are explained in detail. Long and complicated sentences are analyzed so that students may know how an English sentence is constructed. Active verbs such as "keep", "take" and "make" are studied with example sentences, and the teacher also helps to enlarge students' vocabulary by introducing other meanings 
and other uses of each word. Idiomatic expressions and sentence patterns are explained and students are drilled on them in class (see Wu 1981). It is emphasized that students must not overlook or misinterpret a single word. As a matter of fact, each item in Intensive Reading is treated so throughly that students can almost memorize it. From the above description, it is fair to say that Intensive Reading is a course for developing language skills rather than a course for teaching how to read. The rationale behind Intensive Reading is the belief in "sentence as language" rather than "text as language" (Johns 1984). It is assumed comprehension of a text will come naturally if every sentence is understood in isolation. Since each sentence is composed of words, the best way to read is to start with every single word.

Extensive Reading is decribed by wu as a course to broaden students' knowledge, enlarge their vocablulary, and help them read fluently and cultivate a feel for the language. Whereas materials for Intensive Reading are chewed slowly and carefully, materials for Extensive Reading are tasted and swallowed. Students are not encouraged to use the dictionary in Extensive Reading, but to guess the meaning of the words. The general definition of Extensive Reading given by wu sounds quite similar to modern reading theory, but in practice, Extensive Reading fails to fulfill its goal. What is practiced in Extensive Reading is not 
qualitatively different from Intensive Reading. Neither in Intensive Reading nor in Extensive Reading are students taught any skills for reading efficiently. Questions raised and answered in the extensive reading class still circle around language points instead of strategies involved in comprehension. Because of the strong influence of Intensive Reading, which is considered the most essential and important course at college, few students are likely to skip over a single sentence without understnading it (Xingfu $\mathrm{Li}$ 1987).

Scovel (1983A) observed in one program the extensive reading class which spent an entire term studying a small Longman paperback on the life of Madame Curie, and because they devoted only a few pages per class on this short text, the class became preoccupied with specific questions on grammar and word meaning inatead of "extenzive gkilla". Most Chinese teachers cherish the illusion that when students have been taught intensive reading skills, extensive reading skills will take care of themselves (Xiaoju Li 1984). As a result, Extensive Reading is often neglected. In some Chinese colleges, Extensive Reading is assigned as homework for students and never taught in class (Xingfu Li 1987). 
Causes for Popularity of Intensive_Reading

The popularity of Intensive Reading may find its roots in Chinese philosophy, culture and basic concept of education. Traces of what was practiced in the time of Confucius can still be found in modern English teaching in China .

The Chinese have a great reverence for education and learning (Scovel 1983), as well as enormous respect for the written word (Maley 1983), both of which are reflected in the traditional way of teaching in China. The Chinese have placed great emphasis on memorization of texts (Chang 1983), and Scovel describes how children are taught to memorize without being asked to understand the meaning of the text. He concludes that "discipline to memorize and learn by rote is believed to be an essential characteristic necessary for successful language learning in China" (p.106). A large number of phrases are remembered by children in the belief that when internalized through repetition, such sentence patterns will be remembered when older and add to the flexibility and creativity of language use (Unger 1971). As an old Chinese saying states: "When one can memorize 300 Tang poems, he is sure to be able to compose poems of his own though he is not a poet."

While global comprehension of a text is often neglected in teaching of reading in China, the understanding of every single word is overemphasized. Enthusiasticaly focusing on 
every single word is seen as diligence and seriousness in learning. When these ideas are transferred to the teaching of English reading, the preference for intensive reading is inevitable. In China when people say he has "learned" an English lesson, they generally mean he has looked up and memorized every single word, and translated and analyzed grammatically every sentence in it. If he can not show them his notebook of new words and grammar items, they say he has learned nothing (Xiaoju Li 1984). Reading has become soundcentered, word-centered, but never meaning-centered in the Chinese classroom. As a result, Chinese teachers and students are quite conscious of the importance that memorizing has played in their language learning and less conacioue of other perceptual and cognitive proceza which occurred as they acquired their native language(L1).

The cultural assumptions and expectations Chinese students and teachers bring to the reading of literature also shape their attitudes toward the reading precess in a second language(L2). Chinese novels and stories have a markedly different literary tradition of rhetorical and narrative conventions that shape the Chinese reader's expectations (Cole et al 1971, Bloom 1978, and Plaks 1977). Western expectations about plot sequence, character development, suspense and motivation are all shaped by those traditions. Chinese schools emphasize reading of literature as a way of learning a language. Chinese students are eager 
to read and understand American literature, but different literary and rhetorical traditions increase the difficulty of their study. Besides, the Chinese students, in contrast to Japanese or Western ESL students, have been essentially deprived of access to background information about Western culture. Even the most diligent of them are not able to bring much background information about American culture to what they read. And without that background information the processing of reading novels, stories and most of all poetry is quite difficult (see Debyasauvarn 1970, Field 1984, and McDermott 1977). Hence, it is quite natural for Chinese students to use intensive reading skills to read literature.

The Chinese believe that the major purpose of reading is to learn correct sentence structure or right use of words. Intensive Reading fits this purpose in learning English as a foreign language. Intensive Reading makes it possible for grammatical rules to be taught devorced from text. Grammatical rules can be singled out, illustrated with examples, memorized and recited by learners. By focusing on individual words and sentences, Chinese teachers may find it easy to avoid discussions of Western ideology so as to be politically safe. Like students, most Chinese teachers are equally lacking the knowledge of the Western world. Therefore, it appeals to them more to teach meaning of individual words and analyze grammatical items than to explain the content of a text (Scovel 1983). 
What is practiced in the intensive reading class can serve as an example of the Grammar-translation method. Unlike the communicative approach or other approaches to langauage learning, the Grammar-translation method does not require that teachers themselves have native-like fluency in the target language. Since most Chinese teachers are not well trained and some of them are even recycled Russian teachers, they feel most at home with the Grammartranslation method. The Grammar-translation method also fits the Chinese stereotype of language training in whinh teachers are authoritative and students are passive. Because of this tradition, Chinese students prefer teachercentered classroom activities to student-centered ones. They often ask for more lectures by their teachers. Chinese Etudente, Egpenially adult atudente, are an bound by the traditional ways of learning that some of them feel uncomfortable with the more humanistic approaches suggested by many modern language methodologists ( $Y u$ 1984).

The vast difference between learning to read Chinese and learning to read English may also account for why the Chinese take close-reading as a major approach in teaching of English reading.

English is composed of abstract symbols (letters) representing units of speech sounds, while Chinese is composed of characters which are primarily meaning-based units. Each Chinese character is equivalent to a morpheme 
or a word (Wang 1973). In order to read Chinese, the beginning reader must learn the meaning of hundreds of distinct characters. Although characters share common elements (radicals) and some of them may suggest phonetic qualities, their meanings and pronunciations essentially must be memorized to be understood. In contrast to the short time (several weeks or months) it takes students to master the alphabetic symbols, Chinese children spend six long years mastering 3,500 distinct characters (Leong 1973 cited in Perfetti 1985). To memorize the characters, Chinese children spend thousands of hours copying them (Liu 1978). Understandably, since the demand on memory for reading characters is so much greater than for reading English words, the Chinese may be more sensitive to each individual English word than are Americans. In other words, because of the influence of Ll training, the Chinese may have a strong tendency to focus on words rather than on global understanding while reading.

The Chinese concept is that anything that is really bad, or does not work, will eventually die out in the process of competition. Most Chinese teachers are reluctant to abandon their traditional ways of teaching simply because they work just fine. Chinese teachers believe that they have been successful in turning out fluent speakers of English and other foreign languages. But Scovel (1983) has found that those fluent speakers of English are not typical 
of the EFL population in China. They are exceptional and generally share the following backgrounds: 1) they usually come from or are associated with a small number of prestigious foreign language institutes or comprehensive universities; 2) they are typically over fifty years of age and spent a large portion of their formative education studying in mission schools or similar institutions where many of their regualar academic classes were conducted in English; and 3) those exceptional users of English are generally highly motivated.

The last but not the least reason for the dominance of Intensive Reading in teaching of English in China is due to the whole Chinese educational system, under which the

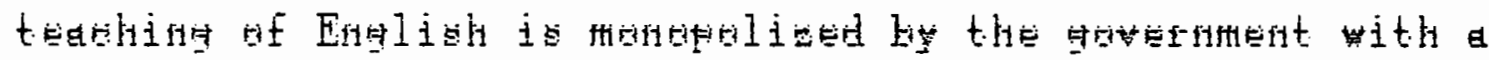
few unified textbooks and uniform curriculum all over the country. With the Russian influence, teachers work together in a teaching group with no ambition for innovations which might lead to potential embarrassement. Ordinary Chinese teachers have little or no say in educational policy-making. Since students' future is often determined by nationwide or university-wide language tests which are geared to the analysis of grammatical items, teachers are in fear that a radical departure from the traditional ways of teaching may put their students at a disadvantage (Maley 1983). 


\section{SUMMARY}

Reading instruction in China as reviewed above is basically "bottom-up", which is characterized by Intensive Reading. Intensive Reading in China, as it is commented by some ESL specialists, reflects a superficial, segregative, and formalistic view of language skills. In America, up-todate reading teachers are very concerned about the students learning to use "top-down" processing, in which students are encouraged to employ the knowlege outside of a text and read as quickly as possible. Reading aloud is viewed as a taboo in the process of ordinary reading because oral reading reduces the reading speed which is essential in reading comprehension. 


\section{CHAPTER III}

\section{METHOD}

To measure the differences between Chinese EFL reading instruction and American ESL reading instruction, three relevant areas were investigated in this thesis: students' ability in reading comprehension, reading instruction in classrooms and ESL/EFL reading textbooks.

\section{SUBJECTS}

To measure the differences between Chinese EFL students and American ESL students in reading comprehension, a reading test was administered to 173 Chinese first-year graduate students of science from Nanjing Aeronautical Institute (NAI) and their counterparts, 63 intermediatadvanced ESL students from Portland State University (PSU). Their comparability was determined by their similar TOEFL scores $(460--500)$.

The Chinese subjects were from 30 cities of nine provinces all over China. Their ages ranged from 22 to 43 with an average age of twenty-nine. Ninety percent of them had received four-year formal undergraduate education and the remaining ten percent of them had received a similar 
education in T.V. universities or in self-taught programs . Sixty-three American ESL subjects were from ten different countries: Japan, Korea, Indonesia, Syria, Pakistan, Equdor, Saudi Arabic, Iran and China. Eighty percent of them had completed their undergraduate education before they came to the United States. The education background of the other twenty percent is not clear. Most of them had been in the ESL program at PSU for more than one year at the time of this study.

There were several reasons for choosing the first-year graduate students of science from NAI as the subjects for the research.

1) In China students are required to pass a nation-wide English proficiency test before they can be admitted to the graduate programs in their interest. Passing that placement test indicates they have met the English proficiency requirements set for undergraduate studies.

2) NAI is one of the key universities in China and privileged to enroll graduate students from all over the country. Therefore, Chinese subjects in this thesis are somewhat representive of graduates of different universities in China.

3) Since most Chinese students who come to the United States have a B.A. or B.S. degree from China and most of them are non-English majors, the first-year graduate students of science from NAI can serve as a good sample to 
see whether the Chinese students are prepared for American universities or not.

The reason for choosing ESL students from PSU as subjects for this study was that the reseacher was studying at PSU and had access to these subjects. It was convenient for the researcher to get information about these subjects from their instructors. It was also through interviewing with those instructors and subjects that the researcher felt confident that these subjects' English proficiency is somewhat similar to that of the first-year graduate students from NAI whare the reseather taght Engliah for two yeara.

\section{PROCEDURES AND DESIGN}

Chinese EFL_Reading Classses and American E ESL Rea

Four Intensive Reading classes of intermediate to advanced level were tape-recorded from the following Chinese universities: Shanghai University (China Tape 1), Hunan Medical College (China Tape 2), Shanghai Foreign Langauge Institute (China Tape 3) and Nanjing University (China Tape 4). China Tape 3 and China Tape 4 are recordings of intensive reading classes of English majors. China Tape 1 and China Tape 2 are recordings of intensive reading classes of non-English majors. Each class lasted about 45 to 50 minutes.

Four classes of ESL reading of intermediate to advanced level were also tape-recorded from the United States. Three 
tapes (U.S.Tape 1, U.S.Tape 2 and U.S. Tape 3) were recorded from PSU and one tape (U.S. Tape 4) from Portland Community College. Each class lasted about 50 to 60 minutes .

All the eight tapes were transcribed and for the convenience of computation, only twenty minutes of each tape, which were randomly selected, have been coded in the categories of reading skills, vocabulary, grammar and pronunciation, which are defined by the researcher as the following ( see Appendix A for sample codeing of the transcriptions).

Reading Skills: any instruction which will guide students in how to understand reading materials, such as predicting, guessing the meaning of a word out of context, discussion of content of a text, skimming, scanning, summarizing the main ideas, identifying the organizational patterns, prereading activities. Direct explanations of vocabulary or grammar were not included in this category.

Vocabulary: direct explanation or definition of words or phrases without using the reading skills defined above.

Grammar: direct analyses of sentense structures or grammatical terms without using the reading skills defined above .

Pronunciation: direct correction of students' pronunciation or oral reading practice.

Any utterances that do not fit into these four 
categories were ignored in coding. If two categories overlaped in one utterance, this utterance was counted as two utterances in two categories. To assure the accuracy of coding, another MA TESOL student was asked to code independently all the utterances trascribed from the tapes and her frequency counts were compared with the researcher's. An inter-rater reliability of rho .95, as measured by Spearman's rank-difference formula, was achieved.

Chinese EFL Reading textbooks and American ESL Reading Textbooks

In order to determine the focus of exercises in Chinese EFL reading textbooks and American ESL reading textbooks, items of exercies in each textbook were coded in the same four categories as they were defined for American ESL reading classes and Chinese EFL intensive reading classes. Any items of exercises that did not fit the four categories were ignored in coding (see Appendix B for sample coding of exercises). Six textbooks were selected for the analysis, three from China and the other three from the United States. All six textbooks were written for intermediate-avanced ESL/EFL students. The three textbooks from the United States have been used in the ESL programs at PSU and at other American univergities. The thres textbooks from China were written by different groups of 
Chinese EFL specialists and approved by Ministry of

Education of China. They are used as intensive reading textbooks in many universities across the country. The proportions of different exercise items in each book were compared through logistic regression analysis as were the proportions of total number of exercises betwen the three Chinese EFL reading textbooks and the three American ESL reading textbooks. The six textbooks analyzed for this study were:

China Text 1--

Li, Guanyi et al 1986. A New English_Course, Shanghai Foreign Language Education Press, Shanghai, China.

China Text 2--

Qu, Xiangju et al 1986. Intensive Reading, Shanghai Foreign Language Education Press, Shanghai, China.

China Text $3--$

Yang, Limin et al 1985. College English, Foreign Language Teaching and Research Press, Beijing, China.

U.S.Text 1--

Markstein, Linda and Louise Hirasawa 1977. Expending

Reading Skills, Newbury House Publishsers, the U.S.A.. U.S. Text 2--

Ramsay, James W.1986. Basic Skiㅣㄴㅗ for Academic Reading, Prentice-Hal1, A Division of Simon and Schuster, Inc. Englewood Cliffs, New Jersey 07632.

U.S. Text 3--

Zukowski/Faust, Jean, Susan S. Johnston and Clarks Atkinson 1983. Between the Lines: Reading Skill ls for Intermediate Lna geuaee, Holt, Rinehart and Winston. 
Reading Ability of Chinese EFL Students and American ESL Students

To measure the difference betwen Chinese EFL students and American ESL students in reading comprehension, a reading test was given to both Amercan ESL students and Chinese EFL students. The test is called Reading Comprehesion which is taken from a series of Descriptive Tests of Language Skills (DTLS), a norm-referenced test developed by the Educational Testing Service for nativespeakers of English (see Appendix C for sample questions of the test). The DTLS Reading Comprehension Test was developed to help teachers diagnose whether college freshmen have the basic reading skills needed for college education. The test deals with three aspects of reading:

1.the ability to recognize main ideas (15 questions). 2.the ability to understand direct statements (13 questions).

3. the ability to draw inferences (17 questions).

The test has no pass or failure scores, but students who fail to answer correctly at least two-thirds of all the questions (45) are considered unprepared for college education. The test was used by the reseacher to answer two questions: 1) compared with American ESL sujects, what percent of Chinese subjects are prepared for college education in the United States in terms of reading ability ? 
2) compared with American ESL subjects, on which aspect of reading do Chinese subjects score lowest?

Sixty-three intermedate-advanced ESL students from PSU (they are also the students of three classes recorded at PSU) and 173 first-year graduate students of science from NAI took the test. In order to measure the correlation between the reading score and the time spent on the test, subjects were not given a time limit for the test but encouraged to do the test as quickly as possible. Subjects' answer sheets were scored separately in the three categories: understanding main ideas, understanding direct statements and drawing inferneces. Forty scores out of 63 from PSU were randomly selected for statistical analysis through one-way ANOVA and so were 40 scores out of 173 from NAI.

The mean time spent on the test from NAI was compared with that from PSU through one-way ANOVA. The mean score of each group was also compared with the mean time spent on the test for correlation through one-way ANOVA.

Some results of the above study support the researcher's hypotheses and some do not. The details of the results of the study will be presented in Chapter IV. 


\section{CHAPTER IV}

\section{RESULTS}

This chapter presents results of statistical comparison in the areas of classroom reading instruction, reading textbooks, reading ability of Chinese EFL students and American ESL students as well as the correlation between reading scores and the time opent on the mompreheneign test.

\section{Chinese EFL_Classroom Reading Instruction_and Amrican ESL}

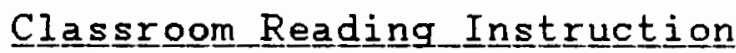

Recordings of eight reading classes were transcribed and coded in categories of reading skills, vocabulary, grammar and pronunciation. Table I presents frequency counts of focus in American ESL reading classes and Chinese EFL reading classes.

The proportions of Chinese teachers' statements about reading skills were compared with those of American teachers' statements about reading skills through logistic regression analysis. Results show that the proportions of teachers' statements about reading skills differed significantly at the .001 level between the two countries. The American ESL reading classes had a higher proportion of 
statements about reading skills (see Table II for the significant difference).

TABLE I

FREQUENCY COUNTS OF FOCUS IN AMERICAN ESL READING CLASSES AND CHINESE EFL READING CLASSES

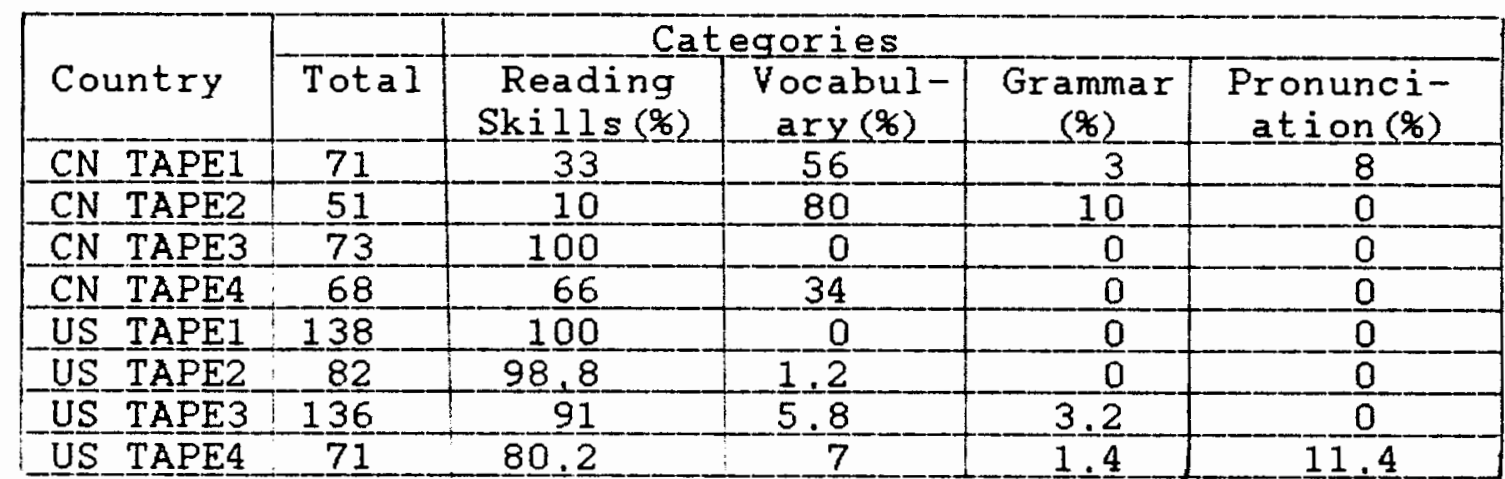

TABLE II

LOGISTIC REGRESSION ANALYSIS FOR READING SKILLS

\begin{tabular}{lccc} 
& Coef & St $\frac{\text { d Err }}{\text { Er }}$ & Coef $/$ SE \\
\hline Intercept & -0.221 & 0.124 & 1.784 \\
Country & 2.825 & 0.265 & 10.639
\end{tabular}

$\mathrm{P}<.001$

The proportions of Chinese teachers' statements about vocabulary were compared with those of American teachers' statements about vocabulary through logistic regression analysis. Results show that the proportions of teachers' statements differed significantly at the .001 level between the two countries. The Chinese EFL reading classes had a 
higher proportion of teachers' statements about vocabulary (see Table III).

TABLE III

LOGISTIC REGRESSION ANALYSIS FOR VOCABULARY

\begin{tabular}{llll} 
& \multicolumn{1}{c}{ Coef } & Std Err & Coef $/ \mathrm{SE}$ \\
\hline Intercept & -0.424 & 0.126 & -3.366 \\
Country & -2.738 & 0.277 & -9.855 \\
\hline
\end{tabular}

$P<.001$

The proportions of Chinese teachers' statements about grammar were compared with those of American teachers' statements about grammar through logistic regression analysis. No significant difference was found $(\mathrm{P}<.001)$, although Chinese EFL reading classes had a somewhat higher proportion (see Table IV).

TABLE IV

LOGISTIC REGRESSION ANALYSIS FOR GRAMMAR

\begin{tabular}{lccc} 
& Coef & Std Err & Coef $/ S E$ \\
\hline Intercept & -3.559 & 0.383 & -9.395 \\
Country & -1.740 & 0.805 & -2.160 \\
\hline NS &
\end{tabular}

The proportions of Chinese teachers' statements about pronunciation were compared with those of American teachers' statements about pronunciation through logistic regression analysis. No significant difference was found (see Table V). 
TABLE Y

LOGISTIC REGRESSION ANALYSIS FOR PRONUNCIATION

\begin{tabular}{lrrr} 
& Coef & Std Err & Coef $/ S E$ \\
\hline Intercept & -3.757 & 0.412 & -9.097 \\
Country & -11.548 & 62.428 & -0.184 \\
\hline NS & & &
\end{tabular}

Chinese EFL Reading Textbooks and American ESL Reading Textbooks

All the exercises in each textbook were coded in categories of reading skills, vocabulary, grammar and pronunciation. The frequency of exercises in each category is presented in Table VI. The proportions of exercises about reading skills are respectively, $68 \%, 31 \%$ and $18 \%$ in the Chinese textbooks and $43 \%, 85 \%$ and $95 \%$ in the American textbooks. The proportions of exercises about vocabulary are respectively, $17 \%, 23 \%$ and $30 \%$ in the Chinese textbooks and $11 \%, 7 \%$ and $1 \%$ in the American textbooks. The proportion. of exercises about grammar are respectively 15\%, $34 \%$ and $52 \%$ in the Chinese textbooks and $46 \%, 8 \%$ and $4 \%$ in the American textbooks. Among the six textbooks analyzed in this study, only CN TEXT 2 has exercises dealing with pronunciation (12\%). 
TABLE VI

PERCENTAGE OF EXERCISES IN CHINESE EFL READING TEXTBOOKS AND AMERICAN ESL READING TEXTBOOKS

\begin{tabular}{|c|c|c|c|c|c|}
\hline \multirow[b]{2}{*}{ Country } & \multirow{2}{*}{$\begin{array}{l}\text { Total of } \\
\text { Exercises }\end{array}$} & \multicolumn{4}{|c|}{ Categories } \\
\hline & & $\begin{array}{l}\text { Reading } \\
\text { Skills }(\%)\end{array}$ & $\begin{array}{c}\text { Vocabul- } \\
\text { ary (\%) }\end{array}$ & $\begin{array}{r}\text { Grammar } \\
(\%)\end{array}$ & $\begin{array}{l}\text { Pronunci } \\
\text { ation }(\%)\end{array}$ \\
\hline CN TEXT1 & 104 & 68 & 17 & 15 & 0 \\
\hline CN TEXT2 & 86 & 31 & 23 & 34 & 12 \\
\hline CN TEXT3 & 132 & 18 & 30 & 52 & 0 \\
\hline US TEXTI & 95 & $4 \underline{3}$ & 11 & $4 \underline{6}$ & O \\
\hline US TEXT2 & 95 & 85 & 7 & 8 & 0 \\
\hline US TEXT3 & 110 & 95 & 1 & 4 & 0 \\
\hline
\end{tabular}

The proportions of exercises about reading skills in the Chinese textbooks were compared with those in the American textbooks through logistic regression analysis. Results show that the proportions of exercises about reading skills differed significantly at the .001 level between the two countries. The American ESI reading textbooks had a higher proportion of exercises about reading skills (see Table VII).

TABLE VII

LOGISTIC REGRESSION ANALYSIS FOR EXERCISES ABOUT READING SKILLS

\begin{tabular}{lccc} 
& Coef & Std Err & Coef $/ S E$ \\
\hline Intercept & -0.505 & 0.115 & -4.395 \\
Country & 1.623 & 0.176 & 9.195 \\
\hline$P<.001$ & &
\end{tabular}

The proportions of exercises about vocabulary in the Chinese textbooks were compared with those in the Americna textbooks through logistic regression analysis. Results 
show that the proportions of exercises about vocabualry differed significantly at the .001 level between the two countries. The Chinese textbooks had a higher proportion of exercises about vocabulary (see Table VIII).

\section{TABLE VIII}

LOGISTIC REGRESSION ANALYSIS FOR EXERCISES ABOUT VOCABULARY

\begin{tabular}{lrrrr} 
& Coef & Std Err & Coef $/ S E$ \\
\hline Intercept & -1.156 & 0.130 & -8.853 \\
Country & -1.583 & 0.274 & -5.760 \\
\hline $\mathrm{p}<.01$ & & &
\end{tabular}

The proportions of exercises about grammar in the Chinese textbooks were compared with those in the American textbooks through logistic regression analysis. Results show that the proportions of exercises about grammar differed significantly between the two countries. The Chinese textbooks had a higher proportion of exercises about grammar (see Table IX).

TABLE IX

LOGISTIC REGRESSION ANALYSIS FOR EXERCISES ABOUT GRAMMAR

\begin{tabular}{cccc} 
& Coef & Std Err & Coef $/ \mathrm{SE}$ \\
\hline Int ercept & -0.608 & 0.116 & -5.215 \\
Country & -0.870 & 0.118 & -4.607 \\
\hline $\mathrm{p}<.05$ & & 0.07
\end{tabular}

The proportions of exercises about pronunciation in the Chinese textbooks were compared with those in the Amercain 
textbooks through logistic regression analysis. No significant differece was found, although the Chinese textbooks had a somewhat higher proportion (see Table X)

\author{
TABLE X
}

LOGISTIC REGRESSION ANALYSIS FOR EXERCISES ABOUT PRONUNCIATION

\begin{tabular}{lrrr} 
& Coef & Std Err & Coef $/ \mathrm{SE}$ \\
\hline Intercept & -3.407 & 0.316 & -10.770 \\
Country & -11.900 & 73.887 & -0.161 \\
\hline NS
\end{tabular}

\title{
READING COMPREHENSION
}

To measure the differences between Chinese EFL subjects and American ESL subjects in reading comprehension, scores from the two groups were compared. Before the data were analyzed by one-way ANOVA, they were checked and found to fit ANOVA assumptions ( normality and homoscedasticity). NAI subject group achieved a mean score of 9.10 in Item 1 (Recognizing Main Ideas) with standard deviation, 2.30. PSU subject group achieved a mean score of 8.05 in Item 2 with standard deviation, 2.55 (see Table XI).

TABLE XI

MEAN AND STANDARD DEVIATION FOR SCORES ON ITEM 1

\begin{tabular}{|c|c|c|}
\hline SCHOOL & NAI & PSU \\
\hline ITEM & 1 & 1 \\
\hline MEAN & $9 \frac{1}{1} \cdot \frac{1}{0} 0$ & 8.05 \\
\hline STD.DEV & 2.30 & 2.55 \\
\hline
\end{tabular}


Scores on Item 1 from NAI were compared with scores on Item 1 from PSU through one-way ANOVA. No significant difference was found (see Table XII)

TABLE XII

ONE-WAY ANOVA FOR SCORES ON ITEM 1

\begin{tabular}{lrrrrrr}
\hline Source of variance & \multicolumn{1}{l}{$S \mathrm{~S}$} & $\mathrm{df}$ & $\mathrm{MS}$ & $\mathrm{F}$ & $\mathrm{P}$ \\
Between-groups & 22.05 & 1 & 22.05 & 3.73 & 0.05 \\
Within-group & 461.50 & 78 & 5.91 & & \\
\hline NS
\end{tabular}

NAI subject group achieve a mean score of 7.07 in Item 2(Understanding Direct Statements) with standard deviation, 2.53. PSU subject group achieved a mean score of 7.77 in Item 2 with standard deviation, 2.52 (see Table XIII)

TABLE XIII

\section{MEAN AND STANDARD DEVIATION} FOR SCORES ON ITEM 2

\begin{tabular}{|c|c|c|}
\hline SCHOOL & NAI & PSU \\
\hline ITEM & 2 & 2 \\
\hline MEAN & 7.07 & 7.77 \\
\hline STD.DEV & 2.53 & 2.52 \\
\hline
\end{tabular}

Scores on Item 2 from NAI were compared with scores on Item 2 from PSU through one-way ANOVA. No significant difference was found (see Table XIV). 
TABLE XIV

ONE-WAN ANOVA FOR SCORES ON ITEM 2

\begin{tabular}{lrrrrr}
\hline Source of variance & SS & df & MS & & F \\
Between-groups & 9.80 & 1 & 9.80 & 1.53 & 0.22 \\
Within-group & 499.75 & 78 & 6.40 & & \\
\hline
\end{tabular}

NS

NAI subject group achieved a mean score of Scores of

8.85 in Item 3 (Drawing Inferences) with standard deviation, 2.78. PSU subject group ahieved a mean score of 8.70 in

Item 3 with standard deviation, 2.60 (see

Table XV).

TABLE XV

MEAN AND STANDARD DEVIATION FOR

SCORES ON ITEM 3

\begin{tabular}{|c|c|c|}
\hline SCHOOL & NAI & PSU \\
\hline ITEM & 3 & $\frac{3}{3}$ \\
\hline MEAN & $8 \frac{8}{8} . \frac{85}{8}$ & $\frac{8}{2} . \frac{70}{0}$ \\
\hline STD.DEV & 2.78 & 2.60 \\
\hline
\end{tabular}

Scores on Item 3 from NAI were compared with scores on

Item 3 with scores on Item 3 from PSU through one-way ANOVA. No significant difference was found (see Table XVI).

TABLE XVI

ONE-WAY ANOVA FOR SCORES ON ITEM 3

\begin{tabular}{lrrrrr}
\hline Source of variance & SS & df & MS & F & P \\
Between-group & 0.45 & 1 & 0.45 & 0.06 & 0.80 \\
Within-group & 565.50 & 78 & 7.25 & & \\
\hline
\end{tabular}


NAI subject group achieved a mean score of 25.03 on the test with standard deviation, 6.29. PSU subject group achieved a mean score of 24.53 on the test with standard deviation, 6.04 (see Table XVII).

\section{TABLE XVII}

MEAN AND STANDARD DEVIATION FOR TOTAL SCORES OF THE TEST

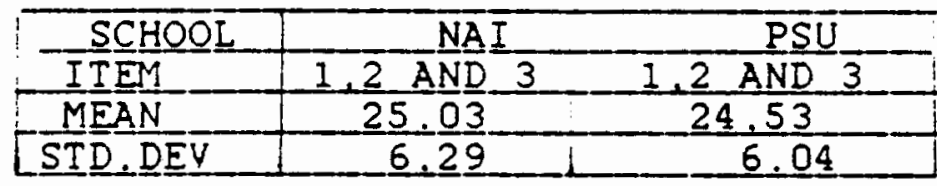

The total scores of the test from NAI subject group were compared with the total scores of the test from PSU subject group through one-way ANOVA. No significant difference was found (see Table VIII).

TABLE VIII

ONE-WAY ANOYA FOR TOTAL SCORE OF THE TEST

\begin{tabular}{lccccc}
\hline Source of variance & $-\frac{S S}{5}$ & df & MS & $F$ & $P$ \\
Between-groups & 296.00 & 1 & 5.00 & 0.13 & 0.71 \\
Within-group & 2966.95 & 78 & 38.03 & & \\
\hline NS
\end{tabular}

To answer the question whether Chinese EFI subjects score lower in Item 1 (Recognizing Main Ideas) and Item 3 (Drawing Inferences) than in Item 2 (Understanding Direct Statements), the proportions of correct responses in each 
item were compared and no significant difference was found (see Table XIX).

\section{TABLE XIX}

ONE-WAY ANOVA FOR PROPORTION OF THE THREE ITEMS IN THE TEST

\begin{tabular}{lcccccc}
\hline Source of variance & SS & df & MS & F & P \\
\hline Between-groups & 0.15 & 2 & 0.07 & 2.53 & 0.08 \\
Within-groug & 3.46 & 117 & 0.29 & & \\
\hline
\end{tabular}

NS

The mean of the time spent on the test from NAI subject group was compared with that from PSU subject group through one-way ANOVA. Results show that the means of the test differed significantly at the .001 level between the two countries (see Table XX).

TABLE XX

ONE-WAY ANOVA FOR MEANS OF THE TEST

\begin{tabular}{lrrrrr}
\hline Source of variance & SS & df & MS & F & P \\
Between-groups & 4032 & 1 & 4042 & 34.36 & 0.000 \\
Within-group & 9154 & 78 & 117 & & \\
\hline NS
\end{tabular}

Chinese EFL subjects spent much more time on the test than American ESL subjects did. The following Figure 3 and Figure 4 show that there is no correlation at all between the testing time and the reading scores among the Chinese subjects, although there is a slight tendency of correlation between the testing time and reading scores among the American ESL subjects. But the results of one-way ANOVA has proved that there is no correlation between the testing time 
and the reading scores on each item in either group (see Table XXI, Table XXII and Table XXIII).

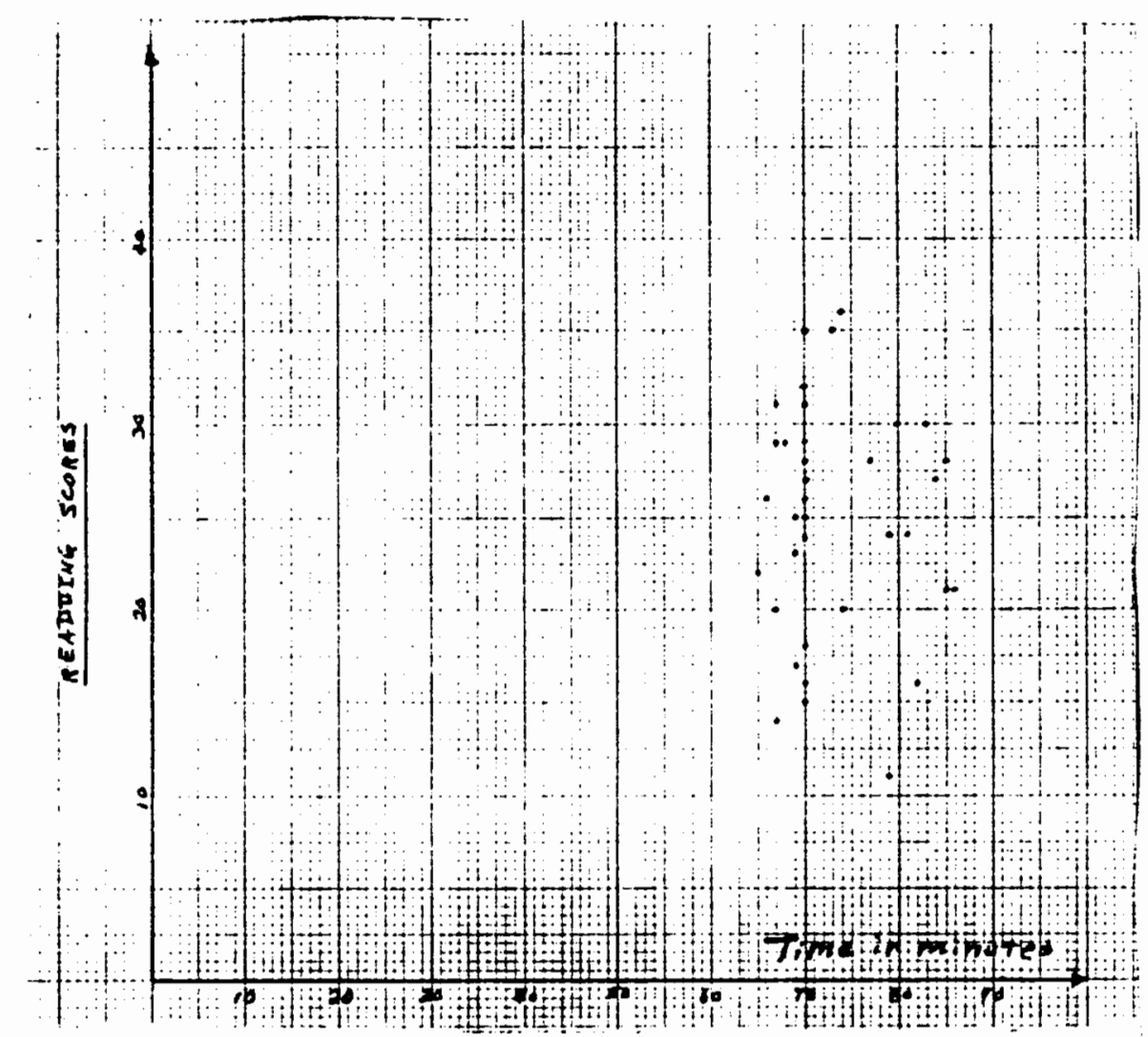

Figure 3. Testing Time and Reading Scores from NAI

TABLE XXI

ONE-WAY ANOVA FOR THE TESTING TIME

AND THE READING SCORES ON ITEM 1

\begin{tabular}{lrrrrr}
\hline Source of variance & SS & df & MS & F & P \\
\hline Country & 4.70 & 1 & 4.70 & 0.80 & 0.37 \\
Time & 9.94 & 1 & 9.94 & 1.70 & 0.19 \\
Error & 51.55 & 77 & 5.86 & & \\
\hline NS & & & & &
\end{tabular}




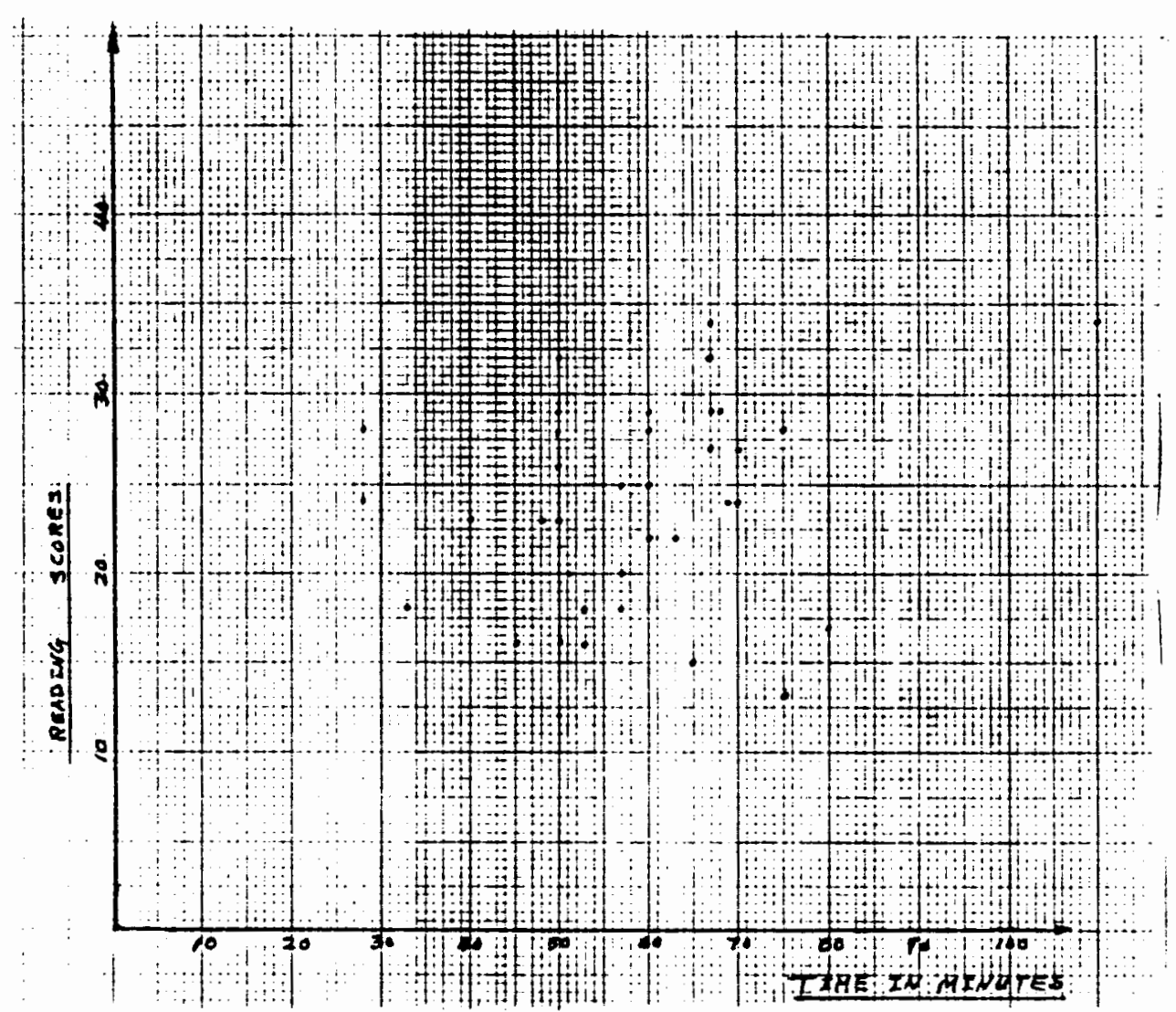

Figure 4. Testing time and reading scores from PSU

TABLE XXII

ONR-WAY ANOVA FOR THE TESTING TIME

AND THE READING SCORES ON ITEM 2

\begin{tabular}{lrrrrr}
\hline Source of variance & SS & df & MS & F & P \\
\hline Country & 19.14 & 1 & 19.14 & 3.01 & 0.86 \\
Time & 10.21 & 1 & 10.21 & 1.61 & 0.20 \\
Error & 489.53 & 77 & 6.35 & & \\
\hline NS & & & & &
\end{tabular}


TABLE XXIII

ONE-WAY ANOVA FOR THE TESTING TIME

AND THE READING SCORES ON ITEM 3

\begin{tabular}{|c|c|c|c|c|c|}
\hline Source of variance & S $\underline{S}$ & $\mathrm{~d} \underline{\underline{f}}$ & MS & F & $\mathrm{P}$ \\
\hline Country & $\begin{array}{l}1.00 \\
0.63\end{array}$ & $\begin{array}{l}1 \\
1\end{array}$ & $\begin{array}{l}1.00 \\
0.63\end{array}$ & 0.14 & $\begin{array}{l}0.71 \\
0.76\end{array}$ \\
\hline Error & 564.86 & 77 & 7.33 & & \\
\hline
\end{tabular}

NS

When the testing time and the total score on the three items were compared through one-way ANOVA, no correlation was found between them (see Table XXIV).

TABLE XXIV

ONE-WAY ANOVA FOR THE TESTING TIME AND THE TOTAL SCORE ON THE THREE ITEMS

\begin{tabular}{lrrrrr}
\hline Source of variance & SS & df & MS & F & P \\
\hline Country & 1.45 & 1 & 1.45 & 0.04 & 0.84 \\
Time & 30.81 & 1 & 30.81 & 0.81 & 0.37 \\
Error & 2936.13 & 77 & 38.13 & & \\
\hline
\end{tabular}

The significance of the findings presented above will be discussed in detail in Chapter $V$. 
CHAPTER $V$

SUMMARY AND DISCUSSION

\section{SUMMARY}

In response to the first research question whether a bottom-up method of reading is taught in Chinese EFL reading classes while a top-down method is taught in American ESL reading classes, proportions of teachers' statements about reading skills, vacabulary, grammar and pronunciation were compared through logistic regression analysis. It was found that proportions of statements about reading skills and vocabulary differed significantly at the .001 level, with the American ESI reading classes having a higher proportion of statements about reading skills and the Chinese EFL reading classes having a higher proportion of statements about vocabulary. Although the Chinese EFL reading classes had somewhat higher proportions of statements about grammar and pronunciation, these proportions were not significantly different $(p<.05)$ when compared with the American ESL reading classes. The second research question asked whether the reading textbooks written by Chinese scholars have a larger proportion of exercises dealing with vocabulary, grammar and 
pronunciation, and a smaller proportion of exercises dealing with reading skills. When proportions of exercises in Chinese EFL textbooks were compared with those in American ESL textbooks through logistic regression analysis, results showed that proportions of exercises about reading skills, vocabulary and grammar differed significantly at the .005 level. The American ESL reading textbooks had a greater proportion of exercises about reading skills while the Chinese EFL reading textbooks had a greater proportion of exercises about vocabulary and grammar. Although Chinese EFL textbooks had a somewhat higher proportion of exercises about pronunciation, no significant difference was found when compared with the American ESL reading textbooks.

In answering the third research question about the strengths and weaknesses of Chinese EFL students in reading comprehension in terms of recognizing main ideas, understanding direct statements and drawing inferences, reading scores from American ESL subjects and Chinese EFL subjects were compared through one-way ANOVA. The statistical comparison of total scores from the two groups and statistical comparison of the proportions of scores in each item either within a group or between groups revealed no significant difference. But it was found that Chinese EFL subjects spent much more time on the test than American ESL subjects did. The mean of the time spent on the test from NAI differed significantly from that from PSU. No 
correlation was found between the testing time and the reading scores in either group, though Figure 4 showed that there is a slight tendency towards correlation between the testing time and the reading scores among the American ESL subjects .

\section{DISCUSSION}

Interpretation of Results

The results in the area of classroom reading instruction generaliy support the author's hypothesis that Chinese teachers in reading classes focus on vocabulary, grammar and pronunciation more often than American reading teachers and less often on reading skills. Since vocabulary, grammar and pronuncaition are defined by the author as language aspects of a text and reading skills as strategies which guide students in comprehending the whole text, the fact that American ESL reading classes had a higher proportion of statements about reading skilis and Chinese EFL reading classes had higher proportions in other categories may lead to the conclusion that a bottom-up method is taught in the Chinese EFL classes while a topdown method is taught in the American ESL classes. This conclusion appears to be valid at least in the classrooms observed for this study.

Transeriftions of the tapes (see Appendix A) show that Chinese teachers' statements about reading skills are mostly 
discussions of content while American teachers' statements about reading skills are mostly discussions of organizational patterns and main ideas. Even in discussing content of a text, American teachers differed from Chinese teachers. American teachers integrated discussion of content with explanation of organizational patterns and other aspects of reading skills. Discussions of content in American ESL reading classes often went beyond the text and teachers made great efforts in introducing background knowledge relevant to the topic in question. In contrast, discussions of content in Chinese EFL reading classes, were generally confined to the text itself and the discussions, proceeding sentence by sentence, were constantly interrupted by the appearance of a new word or phrase. The transcriptions show that Chinese instructors were extremely conscientious in assuring that every new word or phrase was understood by their students. It can also be seen from the transcriptions that Chinese teachers read frequently from the text. This was rare in the American ESL reading classrooms observed.

As in Table I, the proportions of teachers' statements about reading skills are respectively 100\%, 98.8\%, $91 \%$ and $80.2 \%$ in the American ESL reading classes and 23\%, $10 \%, 100 \%$ and $66 \%$ in the Chinese EFL classes, Table VI shows that proportions of exercises about reading skills are respectively $68 \%, 31 \%$ and $18 \%$ in the Chinese EFL reading 
textbooks and $43 \%, 85 \%$ and $95 \%$ in the American ESL reading textbooks.

From the above data, it can be seen, in terms of reading skills, that only $\mathrm{CN}$ TAPE 3 and CN TEXT 1 , are compatible with their American counterparts. As a matter of fact, proportions of each item distributed in CN TAPE 3 and and CN TEXT 1, are similar to proportions of each item distributed in American tapes and texts. CN TEXT 1 happened to be the textbook used in the classroom of CN TAPE $3 . \mathrm{CN}$ TEXT 1, A New English Course written by Guanyi Li in 1986 was designed as a textbook which combines traditional Chinese methods with Western methods. Among the three Chinese ESL textbooks analyzed in the thesis, Li's textbook is the only one that deals with reading skills such as summarizing main ideas and discussing organizational patterns of a text. CN TAPE 3 is a recording of a televised reading class which was intended to demonstrate how to use CN TEXT 1. Both CN TAPE 3 and TEXT 1 stood out as conspicuously different from other Chinese textbooks and recordings of reading classes in that CN TAPE 3 and CN TEXT 1 have a much higher proportion dealing with reading skills than with vocabulary, grammar and pronunciation. What was found in CN TAPE 3 and CN TEXT 1 , is still at the experimental stage in China, but the new content found in $\mathrm{CN}$ TAPE 3 and CN TEXT 1 indicates a methodological shift of 
focus from vocabulary, grammar and pronunciation to reading skills.

Results of logistic regression analysis also show that proportions of exercises dealing with reading skills, vocabulary and grammar in American ESL textbooks differed significantly from proportions of exercises dealing with the same items in Chinese EFL textbooks. The pattern of proportions dealing with different exercises in American ESL textbooks and Chinese EFL textbooks is in comformity with proportions of different statements found in American ESL reading classes and Chinese EFL reading classes. American ESL textbooks have a higher proportion of exercises about reading skills and a lower proportion of exercises about other items, whereas the reverse is true with Chinese EFL textbooks. This suggests that the rationale behind textbooks chosen from both countries is the same as the rationale behind what is practiced in reading classrooms.

A close look at American ESL textbooks reveals that there is also a large proportion of exercises dealing with vocabulary and grammar, but these exercises were designed methodologically different from those found in Chinese EFL reading textbooks. In Chinese EFL reading textbooks, vocabulary and grammar are dealt with in isolation. In American ESL reading textbooks vocabulary and grammar were attacked in context and vocabulary exercises are designed so that that students can guess the meaning of a word out of 
context whenever the context is available. Grammar exercises are always intermingled with discussion of content ( see Appendix B).

One reason why no significant difference was found in the proportions of exercises about pronunciation is that there are not enough pronunciation exercises to be compared with each other. Five out of six textbooks analyzed contain zero proportion of pronunciation exercises. It seems that most intermediate-advanced ESL/EFL reading textbooks no longer treat pronunciation as a major problem in connection with reading, though pronunciation is still emphasized in Chinese EFL reading classes.

Although the preceding data support the researcher's hypothesis that Chinese EFL reading classes and textbooks tend to focus on vocabulary, grammar and pronunciation more often than American ESL reading classes and textbooks, and less often on reading skills, the scores of reading comprehension tests given to both American ESL subjects and Chinese EFL subjects do not support the researcher's hypothesis that Chinese EFL subjects would score lower in all items than American ESL subjects or that Chinese EFL subjects would score lower in understanding main ideas and drawing inferences than in understanding direct statements. This contradiction might suggest classroom reading instruction is not correlated with students' performance in reading. There might have been other factors which are as 
important as classroom reading instruction in determining students' reading performance. One such factor is motivation.

Most Chinese students are highly motivated because how well they learn English determines how well they can do in their future work. Most Chinese students do not mind several hours a day doing boring pattern drills or difficult translation exercises. They expect and welcome a large quantity of home work. This may explain, to a certain extent, why the traditional method is still working in China (Zhuang 1988).

Although Chinese EFL subjects scored similar to their American counterparts in the comprehension test, their mean score was still below 30. Most of them responded correctly to less than two-thirds of all the questions. Among 40 Chinese EFL subjects, only 10 subjects scored above 30 (see Appendix D). According to the Educational Testing Service, Reading Conprehension Test from Descriptive Tests of Language Skills (DTLS) was designed so that most students entering college would answer at least two-thirds of the questions correctly on the test (see DTLS Manual). Therefore,t hose Chinese subjects who scored lower than 30 could be said to be unprepared for college education or at least need some special help in the area of reading. Among 40 American ESL subjects, only 4 subjects scored above 30 (see Appendix D). This may explain why they are still 
studying English in the ESL program instead of studying in the programs of their interest at universities.

The DTLS Reading Comprehension Test was originally designed for native English speakers to complete within 30 minutes. For the sake of the research, neither American ESL subjects nor Chinese EFL subjects were given a time limit for the test, but they were encouraged to do the test as quickly as possible. The time record shows that most Chinese EFL subjects and American ESL subjects spent more than 30 minutes to complete the test. The only American ESL subject who completed the test in 28 minutes scored 28 . The shortest time some Chinese EFL subjects spent on the test was 67 minutes.

Figure 3 and Figure 4 show that although the Chinese EFL subjects and the American ESL subjects scored similarly on the reading comprehension test, there was a big difference in time range. The Chinese subjects required 67 to 85 minutes to complete the test while the time for the American ESL subjects to complete the test ranged from 28 to 110 minutes. There was little difference in speed of reading among the Chinese EFL subjects, although their scores showed a great difference. The similarity of the reading speed among the Chinese EFL subjects might suggest the similarity in their processing the information. If all of them read the test word by word, sentence by sentence, as they were taught in the intensive reading classes, the 
difference in their reading speed would not be great. This assumption comforms with Xingfu Li's conclusion about his Chinese students' ability to read English. Xingfu Li (1987) found that eighty percent of his Chinese students did not know how to read English. They tended to read aloud or word by word. They lacked the ability to vary their speed and strategies in reading different materials.

The reaulte of thia study also show there was no correlation between the testing time and the reading scores. This contradicts what some experts stated, as reviewed in Chapter II of this thesis: that the speed of reading contributes to the efficiency in comprehension, which means that the faster we read, the better we understand (Miller 1967 and Goodman 1965). The findings in this study suggest that fast readers or slow readers may or may not comprehend well. The speed of reading should be controlled by our comprehension ability, not vice versa. It makes little sense to read slowly if one can read rapidly and still understand the materials. If the reader can not understand what $s /$ he is reading, then a slow rate or close-reading is necessary. The crucial question is: when is the closereading necessary?

Recent research (see Perfetti 1985) supports the contention that close-reading strategies should be activated after global reading strategies have proven insufficient for comprehension. They ought not, as in the Chinese 
"intensive" reading classroom, to altogether precede or replace global reading. In other words, in reading beyond the most elementary level, "top-down " processing is applied before "bottom-up" processing. Once a reader is highly skilled, "top-down " and "bottom-up processing may occur simultaneously. It is precisely when "top-down "processing is not sufficient to bring forth comprehension or there is a break-down in comprehension that ESL/EFL students need to know how to go back and use "bottom-up" strategies. As Fischer-Kohn (1986) stated, the close-reading strategies they need to apply are not confined to analysis of grammatical structures, but include analysis of the semantic and logical implications of particualar lexicons and propositions .

Fischer-Kohn found that at her university in the United States, many freshmen, immigrant students who graduated from American high schools, were not used to analyzing text. She reasoned that with little skill in close-reading strategies, these ESL students were in some sense more disadvantaged and fared more poorly in higher education than the ESL students from China. For example, they often had little metacognitive knowledge--knowing when they know--to enable them to monitor failures in their comprehension. In addition, some were so accustomed to graded, adapted readings with superficial content and over-simplified structures, that 
they did not realize that comprehension of authentic college reading is the product of mental effort.

According to Bransford and McCarrel (1974), skilled reading is a creative process, in which understanding is created within the reader, rather than in the text. Some ESL students, who can not effortlessly grasp the content of a passage, may simply give up because of difficulty, rather than analyzing it bit by bit, as students trained in "intensive", or close-reading, strategies would.

\section{Limitations of the Study}

The present thesis was designed to describe and compare the differences between Chinese EFL reading instruction and American ESL reading instruction. But there are so many differences that it is impossible to include all of them in one thesis. Therefore this thesis covers only some major differences in reading instruction. The research part of the thesis covers only some of the differences reviewed in Chapter II.

The eight reading classes observed and analyzed in this thesis are not necessarily representative of American ESL reading instruction and Chinese EFL reading instruction. Since the focus of reading classes may change at different times within the same term in accordance with curriculum, it is possible for one period of a reading class to focus entirely on vocabulary and another period entirely on 
reading skills, even though taught by the same instructor at the same school. By recording one instructor only once, the reseacher may have missed something entirely different, but equally emphasized by the same instructor on a different day.

The same problem occurs with choosing reading textbooks for analysis in this thesis. Since the publication of textbooks is quite limited in China, the author is certain that textboks chosen from China are the most popular ones and these textbooks express the rationale or shift of rationale (for example,CN TEXT 1) behind reading instruction in China. But there is such a variety of textbboks available in the United States that it is difficult to decide what textbooks are the most popular in the United States. The researcher talked with a number of publishers at the TESOL Convention' 88 at Chicago, but failed to get an answer for the above question. So as the last resort, the researcher chose three American ESL reading textbooks on the recommendation of his professors. The comparability of three reading textbooks from China and another three from the U.S. may have been affected by the researcher's choice of books.

Although the testing time of each subject was recorded, the recorded time, however, was the total time of testing. How each subject varied his or her speed in reading different passages of the test was not investigated. Why 
some subjects completed their tests faster than others is still a question for further reseach. If the investigation of the study in the areas of classroom reading instruction, reading textbooks and reading comprehension had been confined to only one group of subjects in each country, the results of the study would have been more accurare in describing the difference between Chinese EFL reading instruction and American ESL reading instruction.

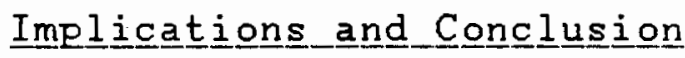

Despite its limitations, this thesis examines some of the major issues concerning Chinese EFL reading instruction and American ESL reading instruction. The research has shown that American ESL reading instruction tends to focus on global understanding of a text while Chinese EFL reading instruction tends to emphasize language aspects of a text. But reading instruction in classrooms is not necessarily correlated with students' performance in reading. There are many other factors outside classroom reading instruction that equally affect students' reading ability. This implies that the Chinese EFL students' performance in reading is not necessarily a direct result from classroom reading instruction and neither is the American ESL students' performance in reading. But this does not mean that classroom reading instruction has no effect at all in shaping students' way of reading. 
Since close-reading is only one component of reading skills, the Chinese teachers in the intensive reading classes should not confine their teaching of English reading just to close-reading. Due to the fact that teaching methods are not always correlated with students' performance, it is understandable that some of the Chinese teachers resist the Western TESOL (Teaching of English to Speakers of Other Languages) methods. They think what they need is knowledge about English language, not TESOL methods .

Chinese habits of teaching are deeply rooted in Chinese culture and the educational system. To change the habits completely is not as easy as some ESL specialists had thought. This leads to the suggestion of modification and compromise. It is a mistake for ESI teachers to arrive in China thinking that they have brought the good news in the form of his up-to-date methods and materials, and it is equally a mistake for Chinese teachers and staff to dismiss foreign techniques and materials as irrelevant.

The fact that the Chinese divide English reading into "intensive reading" and "extensive reading" is certainly an indication that they have realized there are differences between close-reading and global understanding, both of which are necessary in fluent reading (Wu 1981). But they have failed to do what they intended to do. "Intensive" reading has not gone beyond the teaching of langauge 
skills, and "extensive" reading provides little information for achieving global understanding of a text. They lack specific techniques in handling these reading courses. The findings of the research also reveal a sign of change in teaching of English as a foreign language in China.

In conclusion, the author would like to quote the suggestions Fischer-Kohn (1986) made.

The ESL teachers of China should draw from and add to modern research findings about the process of reading comprehension of textual materials. Reading teachers in the United States can learn from the Chinese about the importance of close-reading as a technique to enhance language skills, just as English teachers in P.R.C. can learn from American teachers the importance of teaching global comprehension (p.35). 


\section{REFERENCES}

Akmajian, A.and F Heny 1975. Introduction to the Principles of Transformational Grammar, M.I.T. Press.

Anderson, R.C. and J.W Pichert 1970. "Recall of Previously Unrecallable Information Following a Shift in

Perspective, "Journal of Verbal Learning and Verbal

Behavior, 17, 1-12.

Anderson, R.C., R. E. Reynolds, D.L. Schallert and

E.T.Goetz 1976. "Frame-works for Comprehending

Discourse( Technical Report No. 12), Urbana: University of Ilinois, Laboratory for Cognitive studies in Education.

Bartlett, F.C.1932. Remembering, Cambtidge: Cambridge Univesity Press.

Bever, T. G. and T.G.Bower 1966. "How to Read without Listening", In Project Literary Reports No.6. Educational Resource Information Center, ED 010312 , January 13-25.

Bloom, Alfred 1981. The Linguistic Shaping of Thought: A study in the Impact of Languages on Thinking in in China and West, Hillsdale, New Jersey: Lawrence Erlbaum.

Bransford, J.D., and M.K. Johnson 1972. "Contextual Prerequisites for Understanding: Some Investigations of Comprehension and Recall, Journal of Verbal Learning and Verbal Behavior, 11, 717-726.

Carrell, Patricia L.1981. "The Role of Schemata in L2 Comprehension," Paper presented at the 15th Annual TESOL Convention, Detroit, Michigan, March .

Carrell, Patricia L. and Joan C. Eisterhold 1983. "Schema Theory and ESL Reading Pedagogy," TESOL Quarterly, Vol. 17,4 , Dec. 533-573. 
Carrell, Patricial L. 1983A. "Some Issues in studying the Role of Schema, or Background Knowledge, in Second Language Comprehension," Paper presented at the 17th Annual TESOL Convention, Toronto, Canada, March.

Carrell, Patricia L. 1983.B "Background Knowledge in second Language Comprehension," Language Learning and Communication, 2(1), 25-33.

Chall, Jeanne 1967. Learning to Read: The Great Debate, New York: McGraw Hill.

Chomsky, Noam 1957. Syntactic structures, The Hague: Mouton .

Chomsky, Noam 1965. Aspects of the Theory of Syntax, Cambridge, Mass.: M.I.T. Press.

Cole, Michael, J. Gay, L. Glick, and D.M. Sharp 1971. The Cultural Context of Learning and Thinking, New York: Basic Books.

Debysavarn, M.L.B. 1970. "Acculturalization and Reading", RELC Journal, Vol.1,1, 82-88.

Dechant, Emerald 1965. Improving of the Teaching of Reading in spite of the Aphabet, New York: Philosophical Library.

Dooling, D.J. and R. Lachman 1971. "Effects of Comprehension on Retention of Prose," Journal of Experimental Psychology, 88, 216-222.

Field, Mary Lee 1984. "A Psycholinguistic Model of the Chinese ESL Reader", In On TESOL'84.

Fischer-Kohn, Elaine 1986. "Teaching of Close-reading for ESL/EFL: Uses and Abuses," ED 271952.

Flesch, Rudolf 1955. Why Jonny Can't Read?, New York: Harper and Row.

Gollasch, Frederick V. 1982. Language and Literacy: The Selected Writings of Kenneth S. Goodman, Vol.II, Routledge and Kegan Paul, London, Boston, Melbourne and Henley.

Goodman, K.S.1965. "A Linguistic Study of Cues and Miscues in Reading," Elementary English, 42,1965,639-643.

Goodman, S.K.1967. "Reading: A Psycholinguistic Guessing Game," Journal of Reading Specialist, 6,1967,126-135. 
Goodman, K.S. (Ed.) 1968. The Psycholinguistic Nature of the Reading Process, wayne state University Press, Detroit, 1968.

Hildreth, Gertrude.1958. Teaching Reading, New York: Holt, Rinehart and Winston, Inc. .

Holmes, Deborah Lott.1971."The Independence of Letter, Word, and Meaning Identification in Reading," Reading Research Quarterly, 6, 3, 394-415.

Huey, E.B. 1968. The Psychology and Pedagogy of Reading, New York: Macmillan, 1908 and Cambridge Mass.: M.I.T.Press.

Jacobs, R.A. and P.S. Rosenbaum 1968. English Transformational Grammar, Waltham, Mass.: Bleidell Publishing Company.

Kolers, P.A.1968. "Reading is Only Incidentally Visual," In Goodman S.K. and J.T Fleming, J.T. (Eds.)

Psycholinguistics and the Teaching of Reading, Newark, Delaware: International Reading Association.

Li, Xingfu 1987. "Intensive Reading, speed Reading and Extensive Reading in China", Foreign Language World(in Chinese), No.2, 21-27.

Ii,Xiaoju 1984. "In Defence of the Communicative Approach" , EFL Journal Vol.38,1, Jan. 1984 .

Liu,Stella 1978." Decoding and Comprehension in Reading Chinese", In Cross-Cultural Perspectives on Reading and Reading Research, 144-155, Newark, Delaware: International Reading Association.

Maley, Alan 1983. "XANADU--A Miracle of Rare Device: The Teaching of English in China", Language Learning and Communication, Vol.2,1, 1983,97-103.

McCracken, Glenn and Walcutt, Charles C. 1970. Lippincott's Basic Reading, Teacher's Edition for Book $E$ (Grade Z), Philadelphia: Lippincott, 1970.

McDemott, R.P. 1977. "The Cultural Context of Learning to Read", In Wenat, Stanley F.(Ed.), Linguistics and Reading Series 1: Issues in Evaluating Reading, Arlington, Virginia: Center for Applied Linguistics.

Mehler,J 1963. "Some Effects of Grammatical Transformation on the Recall of Engish Sentences," Journal of Verbal Learning and Verbal Behavior, $2,1963,146-351$. 
Mehler, J. and G. A. Miller 1964. "Retroactive Interference in the Recall of Simple Sentence," British Journal of Psychology, 55, 1964, 295-301.

Miller, G.A. 1967."The Magical Number Seven, Plus or Minus Two: Some Limits on our Capacity for Processing Information," In G.A.Miller. The Psychology of Communication, 14-43.

Patrie, James and David A. Daum 1980. "Comments on the Role of Foreign Expertise in Developing Nations: A Summation of Findings of an Exchange of ESL Specialists with the People's Republic of China," TESOL Quarterly, September, 1980,207-209.

Perfetti, Charles A. 1985. Reading Ability, New York: Oxford University Press.

Placks, Anderew(Ed.) 1977. Chinese Narrative: Critical and Theoretical Essays, princeton, New Jersey: Princeton University Press.

Ruddell, Robert B. 1972. "Psycholinguistic Implication for a System of Communication Model," In Kenneth S. Goodman and James T. Fleming (Eds.), Psycholinguistics and. the Teaching of Reading, International Reading Association, Six Tyre Avenue, Newark, Delaware, 19711 .

Scovel,Janene 1983. "English Teaching in China: A Historical Perspective", Language Learning and Communication, Vol.2, 1, 1983,105-110.

Scovel, Thomas 1983. "The Impact of Foreign Experts, Methodology and Materials on English Language Study in China", Language Learning and Communication, Vol.2,1, 1983,83-90.

Slobin, D.I."The Role of Imitation in Early Language Learning," Paper presented at a symposium on "Interactjion of Thinking and Language in Development" at the biennial meeting of the society for Research in Child Development, Minneapolis, Minnesota, March, 1965.

Smith, E.Brooks, Kenneth S. Goodman and Robert Meredith 1976. Language and Thinking in School, New York: Holt, Rinehart and wixton. 
Smith, Nile Banton.1965. American Reading Instruction: Its Development and Its significance in Gaining a Perspective on Current Practice in Reading, Newark, Del., International Reading Association, 1965.

Smith, Frank and K.S.Goodman 1971. "On Psycholinguistic Method of Teaching of Reading", Elementary School Journal, 177-181.

Smith, Frank 1971. Understanding Reading---A Psycholinguistic analysis of Reading and Learning to Read, Holt, Rinehart and Winston, Inc..

Smith, Frank(Ed.), 1973. Psycholinguistics and Reading, New York: Holt, Rinehart and winston, Inc.

Smith, Frank 1978. Reading, Cambridge, United Kingdom, Cambridge University Press.

Spiro, R.J. and Ann Myers 1984. "Individual Differences and Understanding Cognitive Process in Reading", In P.David Pearson and Michael Kamil(Eds.), Handbook of Reading Research, 471-501.

Strickland, Ruth.G. 1964. The Contribution of structural Linguistics to the Teaching of Reading, Writing in the Elementary school, Bloominton.

Taylor, E.A.1957. "The Spans: Perception, Apprehension, and Recognition," American Journal of Ophthelmology, $44,1957,501-507$.

Unger, Jonathan 1977. "Post-Cultural Revolution Primary School Education: Selected Texts", Chinese Education, Vol.10,2, 4-29.

Wang,William S.Y. 1973. "The Chinese Language", Scientific America, Vol.228,2,50-60.

Wardhaugh, Ronald.1972. "The Teaching of Phonics and Comprehension: A Linguistic Evaluation," In K.S. Goodman and James T. Fleming(Eds.) Psycholingistics and the Teaching of Reading.

Weber, R.M.1968. "The study of Oral Reading Errors: A Survey of the Literature," Reading Research Qaurterly, 4,1968, 96-119.

Wu, Bing 1981. "Beijing Foreign Language Institute and Its English Teaching", ED 205049. 
Yu, Chenchung 1984. "Cultural Principles Underlying English Teaching in China", Language Learning and

Communication, Vol.3,1, 1984, 29-39. 
APPENDIX A

SAMPLE CODING OF CLASSROOM READING INSTRUCTION

R - READING SKILLS V V VOCABULARY G - GRAMMAR
P - PRONUNCIATION

SAMPLE CODING OF US TAPE 1

Teacher(T): The way particularly I noticed in your papers these days is that you are not always getteing main ideas (R). I think because sometimes you look at each other and then you come to look at the whole thing, it is hard to undersstand (R). What is the hat is the whole thing (R)? I don't understand whether hands are important or the face is more important, or nose ( $R$ )? I remember I told this in class before when you see a person walking down in the street, so far away you can't see, you don't start saying, " Ah, that person has gray hair and I have seen that nose on one of my neighbors," and then go on, "Ah she is smiling, oh, she is not "(R). And then you go down and see the shoes and say, "Ha, that's Mrs. Morel"(R). You don't do that on the street (R). You look at the whole person and and say," I know that is Mrs. Morel" (R). Then you may notice I have done something different with my hair (R). So when we look at a person we recognize the whole thing(R). When we study the United states, when we read something, we do the same thing (R). We look at the whole thing first (R). We look at the main idea and then we think how those things relate to the whole thing, the main idea (R). And that is the problem you are having. I think, sometimes, students focus on parts instead of the whole (R). I remember someone says that "the whole thing is greater than some of its parts"(R). When you add all the pieces together, when you get through, you get something more than pieces $(R)$. And I think the same thing is true with an idea, true with people, true with everything $(R)$. We have the philosophy that the whole is more important for you and read to understand 
the generalization(R). It can't be the color of someone's hair or the fact that he is wearing glasses (R). It is the whole idea (R). A generalization is composed of two parts, one part of generalization identifies the topic, what we are talking about and the other part of generalization is a comment on that topic (R). The comment says about what we are going to say about this topic(R). So topic and comment make the main idea of generalization ( $R$ ).

SAMPLE CODING OF CHINA TAPE 1

Teacher(T): Any places you don't know the meanings and the structures in grammar?

$T$ : oK. if not, then I'll ask you. "There are a new phenomenon... $97 \%$ of all the full-time scientists who were hired are still alive". How to explain the sentence (R)?

student (S): inaudible

$T$ : Why is it a new phenomenon (R)?

S: It is a new phenomenon because ... (inaudible).

T: That is right. $97 \%$ of the full-time scientists(R). What is "full-time"?

SS: Professional.

$T$ : Professional, and that means they are paid most of time, 8 hours, 10 hours or more than 10 hours on research (R). So it is not the amateurm, just use spare time to do the scientistic discovery $(R)$. So some of them are full-time, that means, since l9th century, have you come across this kind of term, "full-time" menas lath century scientists (R)? I can hardly find this too from the dictionary, but one of students mentioned this. "Full-time", here, I think, is professional and they are main scientists(R). They do some discovery and innovation(R). So "ever-lived" modifies" the scientists (G). They are still alive, and so that is a new phenomenon(R). They have responsibility for the society and they know their discovery should be benificial to the society(R). It is not something bad to the society, so they know their own moral responsibility(R).

$\mathrm{T}$ : So you have no questions on this ? And another program 
they mentioned in the next 4 and 5 lines. The usual charge leveled at the scientists is that they should not let thier discovery to be used harmfully (R). Here "charge" means... $(R, V)$. It means

"accusation" $(R, V)$. "He is in charge of work here"( $R, V)$. That means his duty, his responsibility $(R, V)$. 
APPENDIX B

SAMPLE CODING OF EXERCISES IN THE READING TEXTBOOKS

READING SKILLS - $R$ VOCABULARY - $V$ GRAMMAR - $G$ PRONUNCIATION - $\mathrm{P}$

SAMPLE CODEING OF EXERCISES FROM CHINESE EFL TEXTBOOKS

1. Give adjectives corresponding to the following nouns(V). symbiosismutualismbiologyeuphemismparasitismcompetitionorganismindividualismecologyimpressionism-

2. Comprehension questions(R)

What might the author be thinking when he writes that human predators the world has known?

What have you learned from the fact the tiger has to make a number of attempts before he succeeds in capturing an animal and that the wolf tends to kill animals that are old, sick or diseased?

3. Read the following paragraph, paying special attention to your pronunciation (P).

4. Complete the following sentences, using so that, as well or as ... as one can $(G)$.

4. Complete the sentences by using infinite phrases(G).

5. Questions for comprehension and appreciation(R): Towards the end, the text says, "When Galileo died...., he left the world...far better informed than it was when he entered it." How much do you know about the level of scientific knowledge of the world in Galileo's time?

Who was Aristotle? How did he come to be worshipped as a kind of God? Was it his fault? Whose fault was it then? Don't you agree there is a lesson for us to learn here? 
6. Give nouns for following $\operatorname{verbs}(V)$.

SAMPLE CODING OF EXERCISES FROM AMERICAN ESL TEXTBOOKS

1.Analysis of ideas and relations: circle the letter next to the best answer(R).

Which statement most clearly expresses the message of this article?

a. Violence on television encourages viewers to act violently.

b. Television is more representive of the real world than it used to be.

c. Television encourages viewers to accept violence passively.

2.Prepositions and Verb-completer: Write any appropriate preposition or verb completer in the blank space (G).

3. Finding main ideas: circle the letter of the item that best states the main idea of each paragraph (R).

4. Vocabulary from context: circle the best answer. Use the reading to guess at the answers ( $R$ ).

5. Look at the key phrase. Then look at the other phrases in "paragraph." Find the key phrase and circle it. you may find the key phrase more than one time in the "paragraph" $(R)$.

6. Find the results of these causes in paragraph 4 and write the results in the spaces (R). 
APPENDIX C

SAMPLE QUESTIONS FROM READING COMPREHENSION TEST

\section{1 - UNDERSTANDIN MAIN IDEAS \\ 2 - UNDERSTANDING DIRECT STATEMENTS \\ 3 - DRAWING INFERENCES}

Although more people than ever are gardening today, there could very well be a decline in gardening in the near future. Studies show a large number of drop-out gardeners, most of them people whose hopes of large savings on food were frustrated by their gardening know-how.

According to the passage, the main reason that many people turned to gardening was to (3)
a. return to the soil
b. spend less money on food
c. gain experience in gardening
d. have supplies of fresh food

Many gardeners become dropouts because
a. they know too little about gardening
b. the cost of gardening is too high
c. it takes too long to learn about gardening
d. gardening is too much work

The main idea of the passage is that (I)
a. gardening is a thing of future
b. people have divorced themselves from nature
c. gardening dropouts are people who give up easily
d. gardening is not as simple as many people think

The college freshmen year is both exciting and puzzling for entering studnets. A sea of new faces, the temptations offered by a relatively loose schedule, and the limitless vistas of new subjects- all of these are appealing to most students. Some of them cannot cope, either emotionally or mentally, with the new sense, but many do so successfully, 
and many of those fail who fail find out years later that they have benefited in some way.

What is the main topic of this passage(1)

a. Why most freshmen fail in college

b. Why college education is valuable to older people

c. Why freshmen fear their first college year

d. Why the freshman year is challenging

The passage suggests that the freshman year is (3)
a. benificial to nearly everyone
b. too loosely structured
c. the best year of college
c. too difficult for most students 


\section{APPENDIX D}

READING SCORES AND TESTING TIME FROM NAI AND PSU

READING SCORES AND TESTING TIME FROM PSU

\begin{tabular}{|c|c|c|c|c|c|}
\hline Subjects & Item 1 & Item 2 & Item 3 & Tota 1 & Time \\
\hline 1 & 7 & 7 & 3 & 17 & 80 \\
\hline 2 & 11 & 12 & 7 & 20 & 51 \\
\hline 3 & 10 & 8 & 10 & 28 & 50 \\
\hline 4 & 5 & 3 & 4 & 12 & 50 \\
\hline 5 & 11 & 12 & 9 & 32 & 50 \\
\hline 6 & 6 & 5 & 4 & 15 & 65 \\
\hline 7 & 5 & 9 & 13 & 27 & 70 \\
\hline 8 & 8 & 8 & 8 & 24 & 70 \\
\hline 9 & 3 & 4 & 5 & 13 & 75 \\
\hline 10 & 10 & 7 & 11 & 28 & 75 \\
\hline 11 & 12 & 11 & 11 & 34 & 110 \\
\hline 12 & 7 & 9 & 9 & 25 & 60 \\
\hline 13 & 8 & 5 & 9 & 22 & 60 \\
\hline 14 & 11 & 7 & 10 & 28 & 60 \\
\hline 15 & 10 & 9 & 10 & 29 & 60 \\
\hline 16 & 7 & 9 & 13 & 29 & 60 \\
\hline 17 & 9 & 9 & 6 & 24 & 38 \\
\hline 18 & 9 & 5 & 9 & 23 & 48 \\
\hline 19 & 5 & 3 & 7 & 16 & 50 \\
\hline 20 & 2 & 6 & 10 & 18 & 33 \\
\hline 21 & 7 & 11 & 15 & 23 & 40 \\
\hline 22 & 11 & 7 & 8 & 26 & 50 \\
\hline 23 & 11 & 12 & 16 & 29 & 67 \\
\hline 24 & 8 & 10 & 9 & 27 & 67 \\
\hline 25 & 5 & 7 & 9 & 22 & 63 \\
\hline 26 & 9 & 7 & 9 & 25 & 57 \\
\hline 27 & 6 & 7 & 7 & 20 & 57 \\
\hline 28 & 7 & 4 & 5 & 16 & 53 \\
\hline 29 & 11 & 6 & 12 & 29 & 50 \\
\hline 30 & 4 & 5 & 7 & 16 & 45 \\
\hline 31 & 7 & 4 & 7 & 18 & 53 \\
\hline 32 & 5 & 7 & 7 & 18 & 57 \\
\hline 33 & 12 & 9 & 11 & 32 & 67 \\
\hline 34 & 11 & 12 & 11 & 34 & 67 \\
\hline 35 & 8 & 11 & 10 & 29 & 68 \\
\hline 36 & 8 & 8 & 8 & 24 & 69 \\
\hline 37 & 10 & 8 & 11 & 29 & 60 \\
\hline 38 & 10 & 10 & 9 & 29 & 60 \\
\hline 39 & 9 & 8 & 11 & 28 & 28 \\
\hline 40 & 6 & 9 & 8 & 23 & 50 \\
\hline
\end{tabular}


READING SCORES AND TESTING TIME FROM NAI

\begin{tabular}{|c|c|c|c|c|c|}
\hline subjects & Item 1 & Item 2 & Item 3 & Total & Time \\
\hline 1 & 11 & 9 & 15 & 35 & 70 \\
\hline 2 & 10 & 3 & 9 & 22 & 65 \\
\hline 3 & 11 & 7 & 7 & 25 & 70 \\
\hline 4 & 6 & 8 & 2 & 16 & 82 \\
\hline 5 & 9 & 7 & 13 & 29 & 67 \\
\hline 6 & 9 & 9 & 9 & 27 & 70 \\
\hline 7 & 7 & 3 & 7 & 17 & 69 \\
\hline 8 & 7 & 4 & 7 & 28 & 70 \\
\hline 9 & 13 & 8 & 10 & 31 & 70 \\
\hline 10 & 13 & 8 & 8 & 29 & 70 \\
\hline 11 & 7 & 5 & 6 & 18 & 70 \\
\hline 12 & 9 & 8 & 9 & 26 & 70 \\
\hline 13 & 12 & 13 & 10 & 35 & 73 \\
\hline 14 & 6 & 2 & 7 & 15 & 70 \\
\hline 15 & 10 & 7 & 9 & 26 & 70 \\
\hline 16 & 8 & 5 & 7 & 20 & 74 \\
\hline 17 & 11 & 7 & 10 & 28 & 85 \\
\hline 18 & 10 & 10 & 11 & 31 & 67 \\
\hline 19 & 11 & 5 & 7 & 23 & 69 \\
\hline 20 & 11 & 9 & 12 & 32 & 70 \\
\hline 21 & 9 & 8 & 12 & 29 & 68 \\
\hline 22 & 7 & 10 & 19 & 26 & 66 \\
\hline 23 & 10 & 9 & 9 & 28 & 77 \\
\hline 24 & 13 & 11 & 12 & 37 & 74 \\
\hline 25 & 7 & 4 & 10 & 21 & 85 \\
\hline 26 & 6 & 4 & 4 & 14 & 67 \\
\hline 27 & 7 & 4 & 5 & 16 & 70 \\
\hline 28 & 8 & 8 & 8 & 24 & 70 \\
\hline 29 & 12 & 11 & 12 & 35 & 70 \\
\hline 30 & 9 & 7 & 11 & 27 & 84 \\
\hline 31 & 9 & 6 & 9 & 24 & 79 \\
\hline 32 & 11 & 7 & 12 & 30 & 83 \\
\hline 33 & 6 & 4 & 10 & 20 & 67 \\
\hline 34 & 8 & 6 & 7 & 21 & 86 \\
\hline 35 & 7 & 7 & 11 & 25 & 69 \\
\hline 36 & 9 & 6 & 11 & 26 & 70 \\
\hline 37 & 10 & 7 & 7 & 24 & 81 \\
\hline 38 & 3 & 6 & 2 & 11 & 79 \\
\hline 39 & 10 & 10 & 10 & 30 & 80 \\
\hline 40 & 12 & 11 & 18 & 31 & 70 \\
\hline
\end{tabular}

